NBER WORKING PAPER SERIES

\author{
ASSIMILATION AND CHANGES IN \\ COHORT QUALITY REVISITED: \\ WHAT HAPPENED TO IMMIGRANT \\ EARNINGS IN THE 1980S?
}

George J. Borjas

Working Paper No. 4866

\author{
NATIONAL BUREAU OF ECONOMIC RESEARCH \\ 1050 Massachusetts Avenue \\ Cambridge, MA 02138 \\ September 1994
}

I am grateful to Julian Betts and Stephen Trejo for helpful comments, and to the National Science Foundation for research support. This paper is part of NBER's research program in Labor Studies. Any opinions expressed are those of the author and not those of the National Bureau of Economic Research.

(C) 1994 by George J. Borjas. All rights reserved. Short sections of text, not to exceed two paragraphs, may be quoted without explicit permission provided that full credit, including () notice, is given to the source. 


\title{
ASSIMILATION AND CHANGES IN COHORT QUALITY REVISITED: WHAT HAPPENED TO IMMIGRANT EARNINGS IN THE 1980S?
}

\begin{abstract}
This paper uses the 1970, 1980, and 1990 Public Use Samples of the U.S. Census to document what happened to immigrant eamings in the 1980s, and to determine if pre-1980 immigrant flows reached earnings parity with natives. The relative entry wage of successive immigrant cohorts declined by 9 percent in the 1970s, and by an additional 6 percent in the 1980s. Although the relative wage of immigrants grows by 10 percent during the first two decades after arrival, the relative wage of post-1970 immigrants will remain 15 to 20 percent below those of natives throughout much of their working lives.
\end{abstract}

George J. Borjas

Department of Economics, 0508

University of California, San Diego 9500 Gilman Drive

La Jolla, CA 92093

and NBER 


\title{
ASSIMILATION AND CHANGES IN COHORT QUALITY REVISITED: WHAT HAPPENED TO IMMIGRANT EARNINGS IN THE 1980s?
}

\author{
George J. Borjas"
}

\section{Introduction}

The 1980s were turbulent years in the history of immigration to the United States Auspiciously enough, the decade began with the Mariel boatlift.' In April 1980, Fidel Castro decided to let Cuban nationals migrate freely to the United States, and over 125,000 people quickly took advantage of this offer. Fueled by charges that perhaps ten to twenty million illegal aliens were overrunning the country, Congress enacted the 1986 Immigration Reform and Control Act, which gave amnesty to about 3 million illegal aliens and introduced a system of employer sanctions designed to stem the flow of illegal workers. Finally, the decade witnessed the continuation of historic trends in the size and national origin mix of legal immigrant flows. During the 1950s, for instance, approximately 252 thousand legal immigrants entered the United States annually, and over two-thirds of these immigrants originated in European countries or Canada. During the 1970 s, the annual flow increased to 449 thousand, with 21.6 percent originating is Europe or Canada, 35.3 percent in Asia, and 40.3 percent in Latin American. By the 1980 s, the annual flow increased to nearly 600 thousand (net of the newly-legalized illegals), with 12.5 percent originating in Europe or Canada, 37.3 percent in Asia, and 47.1 percent in Latin America (U.S. Immigration and Naturalization Service, 1993, pp. 27-28).

\footnotetext{
${ }^{1}$ Card (1990) provides an excellent study of the impact of the .1farielitos on Miami's habor market.
} 
These shifts in the "immigration market" were accompanied by equally important changes in our understanding of the economic impact of immigration. Two new stylized facts, first reported in Borjas (1985), drastically altered the perception of what iismigrants contribute to the economy's skill endowment. First, the skills of successive immigrant cohorts relative to natives declined during much of the postwar period, with the decline accelerating in the 1970s. Second, because of these sizable cohort effects, there was much less convergence between the earnings of immigrants and natives than was previously believed. The combination of relatively low skills and sluggish wage growth suggested that the immigrants who arrived in the 1970 s would not attain wage parity with U.S.-born workers during their working lives.

Because of the controversial implications of these results, there has been a great deal of debate concerning their validity (Chiswick, 1986; Duleep and Regets, 1992; Friedberg, 1992; Funkhouser and Trejo, 1995; LaLonde and Topel, 1992; and Yuengert, 1994). ${ }^{2}$ Most studies in the literature conclude that the relative skills of immigrant cohorts indeed declined substantially during the 1960s and 1970s, and that much of the decline can be attributed to changes in the national origin mix of immigrant flows. Because immigrants who originate in less-developed countries do not perform as well in the U.S. labor market (Borjas, 1987), the shift in the national origin mix away from the traditional European source countries towards Asian and Latin American countries generates a less "successful" immigrant flow.

The literature, however, has not reached a clear consensus on whether the age-earnings profile of immigrants converges to that of natives within a decade or two after arrival, as suggested by the original cross-section work of Chiswick (1978) anci Carliner (1980). The

\footnotetext{
${ }^{2}$ A number of studies also address similar issues for other immigrant-receiving countries. See. for example. Baker and Benjamin (1994), Kee and Van Ophem (1992), and Pischke (1993)
} 
confusing results in the literature, however, partly reflect differences in the selection of the "base" to whom immigrants are compared. Some studies, for example, compare the immigrants to the typical native-born person in the United States; while other studies define the native base as the sample of U.S.-born workers who share the same ethnic background as the immigrants.

Much of the debate over the trends in the skill endowment and economic performance of immigrants is based on data drawn from the 1980 decennial Census (and earlier Censuses). ${ }^{3}$ This paper uses the 1970,1980, and 1990 Public Use Samples of the U.S. Census to document what happened to the earnings of immigrants during the 1980s, and to determine if pre-1980 immigrant flows have reached earnings parity with natives. To provide as convincing an analysis as possible, much of the empirical evidence reported in the paper is based on "raw" statistics drawn directly from the Census. These calculations do not impose any type of parametric or statistical structure on the data. Although I also provide a more formal statistical analysis based on a regression model that allows the identification of aging, cohort, and period effects, the regression results simply provide another way of packaging the key insights revealed by the raw Census data.

The study contains a number of potentially important empirical results. First, the decline in the relative wage of successive immigrants waves continued into the $1980 \mathrm{~s}$. As compared to the precipitous drop observed during the 1970 s, however, the rate of decline slowed in the 1980 s. Second, the evidence suggests that the earnings of post-1970 immigrant will never reach parity with the earnings of the typical U.S.-bom worker. Further, the earnings of Mexican and Asian immigrants, the two groups making up the bulk of recent immigration, will not converge to the

${ }^{3}$ Funkhouser and Trejo (1995) analyze immigrant labor market performance during the 1980 s using selected supplements of the Current Population Surveys (CPS). As noted below, the number of immigrants in these data is very small, and inferences regarding trends in immigrant skills may be unreliable. 
earnings of natives with Mexican or Asian ancestry. Overall, the attainment of wage parity jetween immigrants and natives does not seem to be an important feature of the labor market experience of many first-generation Americans.

\section{Data and Summary Statistics}

The analysis uses the 1970,1980 and 1990 Public Use Samples of the U.S. Census. A person is classified as an "immigrant" if born in a foreign country; all other workers are classified as "natives". ${ }^{4}$ I extracted a 1/500 random sample of natives from each of the decennial Censuses. The 1970 immigrant extract is composed of a $2 / 100$ sample (created by combining the $1 / 100$ State and County Group files), while the 1980 and 1990 immigrant extracts are a 5/100 random sample from each respective Census. The study is restricted to men aged $25-64$ who work in the civilian sector, who are not self-employed, and who do not reside in group quarters. Finally, because the Public Use Sample of the 1990 Census (unlike the earlier Censuses) is not a random sample of the population, the sampling weight is used throughout the calculations.

The first three columns of Table 1 reports the difference in the average log wage rate between immigrants and natives." These statistics document a number of important results. There was a steady decline in the average wage of immigrants relative to natives between 1970 and 1990. In 1970, the typical immigrant earned about 1 percent more than natives; by 1980 , the

4 Persons born abroad of American parents and persons born in a U.S. possession are also classified as natives.

3 The wage rate is defined as the ratio of annual earnings to hours worked in the previous calendar year. In the 1980 and 1990 Censuses, hours worked are given by the product of wecks worked times usual hours worked per week. In the 1970 Census, annual hours worked are given by the product of wceks worked times hours worked last week. Workers who reported an hourly wage rate below $\$ 1$ and over $\$ 250$ (in 1989 dollars) are omitted from the analysis. 
TABLE 1

IMMIGRANT LOG WAGE, 1970-1990

(Relative to Natives)

\begin{tabular}{|c|c|c|c|c|c|c|}
\hline \multirow[b]{2}{*}{ Group: } & \multicolumn{3}{|c|}{ Unadjusted Wage Differential } & \multicolumn{3}{|c|}{$\begin{array}{c}\text { Age-Adjusted Wage } \\
\text { Differential }\end{array}$} \\
\hline & $\underline{1970}$ & $\underline{1980}$ & $\underline{1990}$ & 1970 & $\underline{1980}$ & $\underline{1990}$ \\
\hline All Immigrants & $\begin{array}{l}.0090 \\
(.0036)\end{array}$ & $\begin{array}{l}. .0966 \\
(.0023)\end{array}$ & $\begin{array}{l}-.1653 \\
(.0020)\end{array}$ & $\begin{array}{l}.0006 \\
(.0059)\end{array}$ & $\begin{array}{l}-.1062 \\
(.0035)\end{array}$ & $\begin{array}{l}-.1727 \\
(.0030)\end{array}$ \\
\hline $\begin{array}{l}\text { Cohort: } \\
\text { 1985-1989 Arrivals }\end{array}$ & -- & -- & $\begin{array}{l}-.3815 \\
(.0035)\end{array}$ & --- & $\cdots$ & $\begin{array}{l}-.3519 \\
(.0042)\end{array}$ \\
\hline 1980-1984 Arrivals & --- & -- & $\begin{array}{l}-.3261 \\
(.0033)\end{array}$ & -- & -- & $\begin{array}{l}-.3060 \\
(.0040)\end{array}$ \\
\hline 1975-1979 Arrivals & -- & $\begin{array}{l}-.3226 \\
(.0041)\end{array}$ & $\begin{array}{l}-.1963 \\
(.0036)\end{array}$ & $\cdots$ & $\begin{array}{l}-.2940 \\
(.0050)\end{array}$ & $\begin{array}{l}-.2049 \\
(.0041)\end{array}$ \\
\hline 1970-1974 Arrivals & -- & $\begin{array}{l}-.2091 \\
(.0041)\end{array}$ & $\begin{array}{l}-.0976 \\
(.0041)\end{array}$ & $-\ldots$ & $\begin{array}{l}-.1999 \\
(.0049)\end{array}$ & $\begin{array}{l}-.1368 \\
(.0044)\end{array}$ \\
\hline 1965-1969 Arrivals & $\begin{array}{l}-.1811 \\
(.0075)\end{array}$ & $\begin{array}{l}-.0807 \\
(.0044)\end{array}$ & $\begin{array}{c}.0113 \\
(.0048)\end{array}$ & $\begin{array}{l}-.1856 \\
(.0081)\end{array}$ & $\begin{array}{c}-.1019 \\
(.0050)\end{array}$ & $\begin{array}{r}-.0279 \\
(.0050)\end{array}$ \\
\hline 1960-1964 Arrivals & $\begin{array}{l}-.0445 \\
(.0082)\end{array}$ & $\begin{array}{l}.0010 \\
(.0051)\end{array}$ & $\begin{array}{l}.0861 \\
(.0053)\end{array}$ & $\begin{array}{l}-.0555 \\
(.0086)\end{array}$ & $\begin{array}{l}-.0260 \\
(.0055)\end{array}$ & $\begin{array}{l}.0411 \\
(.0057)\end{array}$ \\
\hline 1950-1959 Arrivals & $\begin{array}{l}.0548 \\
(.0063)\end{array}$ & $\begin{array}{l}.0551 \\
(.0041)\end{array}$ & $\begin{array}{l}.1793 \\
(.0051)\end{array}$ & $\begin{array}{l}.0425 \\
(.0067)\end{array}$ & $\begin{array}{l}.0400 \\
(.0048)\end{array}$ & $\begin{array}{l}.1128 \\
(.0056)\end{array}$ \\
\hline Pre-1950 Arrivals & $\begin{array}{l}.0980 \\
(.0055)\end{array}$ & $\begin{array}{l}.1011 \\
(.0052)\end{array}$ & $\begin{array}{l}.2328 \\
(.0093)\end{array}$ & $\begin{array}{l}.1309 \\
(.0075)\end{array}$ & $\begin{array}{l}.0883 \\
(.0063)\end{array}$ & $\begin{array}{l}.1716 \\
(.0098)\end{array}$ \\
\hline Sample Size: & & & & & & \\
\hline $\begin{array}{l}\text { Immigrants } \\
\text { Natives }\end{array}$ & $\begin{array}{c}32,859 \\
146,468\end{array}$ & $\begin{array}{l}135,991 \\
182,273\end{array}$ & $\begin{array}{l}212,946 \\
210,163\end{array}$ & $\begin{array}{c}32,859 \\
146,468\end{array}$ & $\begin{array}{l}135,991 \\
182,273\end{array}$ & $\begin{array}{l}212,946 \\
210,163\end{array}$ \\
\hline
\end{tabular}

Notes: Standard errors are reported in parentheses. Each native extract is a 1/500 random sample from the respective Census. The 1970 immigrant extract is a $2 / 100$ random sample, while the 1980 and 1990 immigrant extracts are $5 / 100$ random samples. The age-adjusted wage differentials are calculated from a regression estimated in each Census cross-section which includes a cubic term in the worker's age and interacts the age variables with an immigrant dummy. The log wage differentials are then evaluated at the age of $\therefore 0$. 
immigrant wage advantage had tumed into an approximate 9.7 percent disadvantage; and by 1990 , the wage gap had grown to 16.5 percent. $^{6}$

The data also document that part of the decline in the relative wage of immigrants can be explained by a sizable drop in the relative wage of successive immigrant cohorts. To provide a simple framework for analyzing these cohort effects, I split the immigrant population into eight waves: 1985-1989 arrivals; 1980-1984 arrivals; 1975-1979 arrivals; 1970-1974 arrivals; $1965-$ 1969 arrivals; 1960-1964 arrivals; 1950-1959 arrivals; and pre-1950 arrivals. These eight cohorts can be precisely identified in all the Censuses. ${ }^{7}$

The latest immigrant wave enumerated in the 1970 Census (i.e., the 1965-1969 arrivals) earned 18.1 percent less than natives in 1970 . By 1980 , the latest immigrant wave enumerated in the 1980 Census eamed 32.3 percent less than natives; and by 1990 , the wage disadvantage between the most recent immigrant wave and natives had grown to 38.2 percent. As long as we are willing to interpret relative wages as a measure of relative skills, the trend in the wage differential between recent immigrants and natives suggests that the relative skill decline across successive immigrant waves continued into the 1980 s, but at a slower rate. During the 1970 s, the relative wage of immigrant cohorts fell by 14 percentage points, and during the 1980 s the relative wage fell by "only" an additional 6 percentage points. ${ }^{8}$

\footnotetext{
${ }^{6}$ To facilitate the discussion of the results, I will refer to the log wage differentials reported in the tables as percentage wage differentials. This approximation is valid only if the log wage differential is "small."

7 A small number of immigrants in the 1970 Census (about 3.2 percent of the sample) did not report the year of migration. These workers are omitted from the analysis. On average, these immigrants have 10 percent lower wages than those who do repor the year of migration.

8 These statistics are obtained by calculating the difference in the relative wage of the 1965-69, 1975-79. and 1985-89 immigrant cohorts.
} 
The statistics reported in Table 1 also seem to indicate an improvement in the relative wage of a particular cohort across successive Censuses. Consider, fc: :nstance, the cohort that arrived in the late 1960 s. The 1970 Census indicates that at the time of entry this group earned 18.1 percent less than natives; by 1980, the wage gap had rarrowed to -8.1 percent; and by 1990 , the cohort had reached wage parity. Similarly, if we con:ider the cohort that arrived in the early $1960 \mathrm{~s}$, the relative wage improved from -4.5 percent in 1970 to +8.6 percent in 1990 . Over a 20 year period, therefore, the relative wage of immigrants grows by perhaps 15 to 20 percentage points.

A number of data and conceptual problems, however, suggest that we should interpret both the trend in cohort effects and the rate of wage convergence reported in the first three columns of Table 1 with some caution. The first problem, and the easiest one to dispose of, arises from differences in the way that topcoded earnings are treated across Censuses. The Census Bureau topcodes annual earnings at $\$ 50,000$ in the 1970 Census and at $\$ 75,000$ in the 1980 Census. I multiplied these topcodes by a factor of 1.5 to approximate the conditional mean earnings for persons at the top of the income distribution. The Census Bureau topcodes annual earnings in the 1990 Census at $\$ 140,000$ and provides an estimate of the conditional mean of the upper tail of the wage distribution. In particular, the 1990 Census reports the median earnings of topcoded persons in the state of residence. If natives and immigrants have different probabilities of being in the upper tail of the wage distribution, it is clear that changes in how topcoded earnings are treated across Censuses could bias the intercensal comparisons

This problem, however, is not empirically important. I constructed an alternative wage series for the 1990 Census by assigning an annual earnings of $\$ 210,000$ (or $\$ 140,000$ times 1.5 ) to all topcoded observations. This assignment replicates how the topcoded observations were 
handled in the earlier Censuses. The relative wage of immigrants in the 1990 Census barely changed when I used this alternative method. ${ }^{9}$

A more serious drawback is that the wage growth experienced by a particular immigrant cohort (as well as the trends in the relative wage across cohorts) is not well represented by the trend in the unadjusted wage differential. For instance, I use the 1970 Census to compare the wage of the typical worker in the 1965-1969 immigrant wave to that of natives aged 25-64. I then use the 1990 Census to again compare the earnings of the same immigrants (i.e., those who arrived between 1965 and 1969) to natives aged 25-64. Because the typical immigrant cohort is aging while the age composition of the native base is held (roughly) constant, the rate of wage growth given by any row in the first three columns of Table 1 overstates the actual wage growth.

To avoid this bias, I calculated the relative wage of immigrants after adjusting for differences in the age composition of the native and immigrant populations. In each Census crosssection, I estimated a regression of the worker's wage on age (introduced as a third-order polynomial), on dummy variables indicating if the worker is an immigrant and which cohort he belongs to, and on interactions of the age variables with the immigrant dummy. The age-adjusted wage differential between immigrants and natives is then evaluated at the age of 40 (which is approximately the mean age of the immigrant sample in both 1980 and 1990), and is reported in the last three columns of Table 1 .

9 If all topcoded observations in the 1990 Census are assigned an annual earnings of $\$ 210,000$. the relative wage for immigrants who arrived between 1985 and 1990 was -.382; for the 1980-1985 arrivals. -.326; for the 1975-1979 arrivals, -.197; for the 1970-1974 arrivals, -.098; for the 1965-1969 arrivals. .011 ; for the 1960-1964 arrivals, .086; for the 1950-1959 arrivals, .180; and for the pre-1950 arrivals. .234. The similarity between these statistics and those reported in Table 1 is not surprising since only .9 percent of natives and .8 percent of immigrants are topcoded in the 1990 Census. 
The data show that the age-adjusted wage differential grows at a slower rate than the unadjusted differential. The unadjusted relative wage of the immigrants who arrived between 1965 and 1969 grew by almost 20 percentage points between 1970 and 1990 . The age-adjusted relative wage of the same immigrant cohort, however, grew by only 16 percentage points Similarly, the unadjusted relative wage of the cohort that arrived in the late 1970 s grew by 13 percentage points during their first 10 years in the United States. Adjusting for age reduces the rate of wage growth to 9 percentage points.

To interpret the trend in the relative wage of immigrants (both within and across cohorts) as a measure of relative changes in skills, we must assume that period effects influence the wages of immigrants and natives by the same relative amount. This assumption introduces a number of problems into the analysis. After all, if we define the wage as the product of the rate of return to skills times the worker's human capital stock, the intercensal changes in relative wages cculd be reflecting differences in prices rather than differences in human capital.

It is well known that there were historic changes in the U.S. wage structure during the 1980s and that these changes did not affect all skill groups equally. In particular, there was a sizable increase in the wage gap between highly educated and less educated workers, and between workers with many years of experience and new labor market entrants (Murphy and Welch, 1992; Katz and Murphy, 1992; Juhn, Murphy, and Pierce, 1993).

It is unlikely that these changes in the wage structure affected the earnings of immigrant and native workers by the same percentage amount. As will be shown below, the immigrant population is relatively unskilled (at least in terms of educational atiainment). Because the rate of return to skills increased during the 1980 s, the relative wage of immigrants would have fallen between 1980 and 1990 even if immigrant skills had remained constant. In other words, the 
changes in the wage structure observed in the past two decades coulc be responsible for both the observed decline in the relative wage of successive immigrant cohorts and for the sluggish wage growth experienced by a particular cohort during the 1980 s.

It is unlikely, however, that controlling for changes in the wage structure could reverse the downward trend in relative wages across successive immigrant cohorts or substantially increase the rate of wage convergence between immigrants and natives. Suppose that instead of analyzing intercensal changes in the relative immigrant wage, we analyze a skill measure that is invariant to changes in the wage structure (at least in the short run); namely, the educational attainment of immigrants. Table 2 documents the changes in the schooling distribution of immigrants and natives between 1970 and 1990. In particular, the table reports the percent of native and immigrant men who are either high school dropouts (i.e., have less than 12 years of schooling) or college graduates (i.e., have at least 16 years of schooling).

The direction of the trend in these rough measures of the "human capital stock" is indisputable. In 1970, 39.6 percent of natives were high school dropouts; by 1990 , only 14.8 percent of natives lacked a high school diploma. Among immigrants, 48.2 percent were dropouts in $1970,37.4$ percent in 1980 , and 36.9 percent in 1990 . Relative to natives, therefore, immigrants were about 21.7 percent more likely to be high school dropouts in 1970 , but are now more than twice as likely to be high school dropouts. Moreover, the fraction of the most recent immigrant wave that is composed of high school dropouts remained at about 36 percent between 1980 and 1990, despite the 8 percentage point drop in the respective statistic among natives. In contrast, even though the fraction of native and immigrant workers who are college graduates rose steadily over the period, the fraction of natives who are college graduates rose even faster. In 1970, immigrants were more likely than natives to be college graduates (18.9 
TABLE 2

EDUCATIONAL ATTAINMENT OF IMMIGRANTS AND NATIVES, 1970-1990

\begin{tabular}{|c|c|c|c|c|c|c|}
\hline \multirow[b]{2}{*}{ Group } & \multicolumn{2}{|c|}{1970} & \multicolumn{2}{|c|}{1980} & \multicolumn{2}{|c|}{1990} \\
\hline & $\begin{array}{c}\text { Percent } \\
\text { High School } \\
\text { Dropouts }\end{array}$ & $\begin{array}{c}\text { Percent } \\
\text { College } \\
\text { Graduates } \\
\end{array}$ & $\begin{array}{c}\text { Percent } \\
\text { High School } \\
\text { Dropouts }\end{array}$ & $\begin{array}{c}\text { Percent } \\
\text { College } \\
\text { Graduates } \\
\end{array}$ & $\begin{array}{c}\text { Percent } \\
\text { High School } \\
\text { Dropouts }\end{array}$ & $\begin{array}{c}\text { Percent } \\
\text { College } \\
\text { Graduates }\end{array}$ \\
\hline Natives & 39.6 & 15.4 & 23.1 & 22.9 & 14.8 & 26.6 \\
\hline Immigrants & 48.2 & 18.9 & 37.4 & 25.3 & 36.9 & 26.6 \\
\hline $\begin{array}{l}\text { Cohort: } \\
\text { 1985-89 } \\
\text { Arrivals }\end{array}$ & $\cdots$ & -- & $\cdots$ & -- & 35.2 & 31.5 \\
\hline $\begin{array}{c}1980-84 \\
\text { Arrivals }\end{array}$ & --- & -- & --- & -.. & 40.4 & 24.1 \\
\hline $\begin{array}{c}1975-79 \\
\text { Arrivals }\end{array}$ & -- & --- & 36.2 & 30.4 & 42.2 & 24.8 \\
\hline $\begin{array}{c}1970-74 \\
\text { Arrivals }\end{array}$ & -- & $--\cdot$ & 44.0 & 24.9 & 42.7 & 24.1 \\
\hline $\begin{array}{c}1965-69 \\
\text { Arrivals }\end{array}$ & 45.2 & 28.3 & 41.6 & 24.7 & 34.1 & 26.2 \\
\hline $\begin{array}{r}1960-64 \\
\text { Arrivals }\end{array}$ & 44.8 & 21.1 & 34.7 & 24.8 & 27.5 & 27.9 \\
\hline $\begin{array}{c}1950-59 \\
\text { Arrivals }\end{array}$ & 47.4 & 17.1 & 31.4 & 23.7 & 25.9 & 27.8 \\
\hline $\begin{array}{c}\text { Pre-1950 } \\
\text { Arrivals }\end{array}$ & 51.7 & 15.0 & 35.3 & 21.6 & 25.2 & 31.8 \\
\hline
\end{tabular}


percent for immigrants as compared to 15.4 percent for natives). By 1990, immigrants and natives had exactly the same probability of being college graduates (26.6 percent). Put differently, the perception that the immigrant population contains a disproportionately high number of college graduates is no longer true.

As a result of the relatively larger number of high school dropouts and the relatively smaller number of college graduates, the mean educational attainment of immigrants relative to natives fell dramatically between 1970 and 1990. In 1970, the typical recent immigrant (i.e., one who arrived in the last five years) had 11.13 years of schooling, as compared to 11.48 years for natives, or a difference of -.35 years. By 1980 , the most recent immigrants had 11.84 years of schooling while natives had 12.72 years, a difference of -.88 years. By 1990 , the most recent immigrants had 11.87 years of schooling while natives had 13.19 years, a difference of -1.32 years. It is evident, therefore, that not only did the relative educational attainment of immigrant cohorts declined between 1970 and 1990, but that the absolute level of immigrant education actually remained constant between 1980 and 1990 (during a period of rapidly rising educational attainment for natives). ${ }^{10}$

It is evident, therefore, that changes in the "quantity" of the fr:man capital of immigrants are partly responsible for the decline in the relative immigrant wage documented in Table 1.

10 The intercensal differences in the level of educational attainment should be interpreted uith some caution because the 1990 Census codes a person's educational attainment in a very different way than earlier Censuses. We do not yet know how the change in the coding of the education variable affects the estimated mean years of schooling for particular groups. To calculate average years of schooling in the 1990 Census, I used the following recoding of the variable giving the highest grade completed: No School completed, Nursery School, Kindergarten $=0$ years; 1 st through 4 th grade $=2.5$ years: 5 th through $8 \mathrm{th}$ grade $=6.5$ years; 9 th grade $=9$ years; 10 th grade $=10$ years; 11 th grade or 12 th grade without diploma $=11$ years; High school graduate $=12$ years; Some college, no degree $=13$ years: Associate degree $=14$ years; Bachelor's degree $=16$ years; Master's degree $=17$ years: Professional or Doctorate degree $=20$ years. 
Moreover, it can be also be shown that the changes in the U.S. wage structure were not of a sufficiently large magnitude to account for a sizable part of the declining relative wages of immigrants across successive cohorts.

Suppose that we use the native population in each of the three Censuses to quantify changes in the wage structure for specific skill groups. In particular, consider splitting the native population into 56 age-education cells. The eight age categories are: $25-29$ years old; $30-34 ; 35$ $39 ; 40-44 ; 45-49 ; 50-54 ; 55-59$; and $60-64$. The seven education categories are: at most 8 years of schooling; 9 years; $10-11$ years; 12 years; $13-15$ years; 16 years; and more than 16 years. For each of these age-education cells, I computed the average log wage of natives in each of the Census years. Let $\bar{y}_{r s}(t)$ be the mean log wage for native workers in age group $r(r=1, \ldots, 8)$, education group $s(s=1, \ldots, 7)$, in Census year $t(t=1970,1980,1990)$. The change in the log wage experienced by skill group rs between 1970 and Census year $t$ is given by:

$$
\Delta_{r s}(t)=\bar{y}_{r s}(t)-\bar{y}_{r s}(1970), \quad t=1980,1990
$$

The variable $\Delta_{r s}(t)$, in effect, gives a "deflator" that can be used to adjust the earnings of workers in the 1980 and 1990 Censuses for changes in the wage structure. The deflated wage in these Censuses is then given by:

$$
\log \hat{w}_{\ell, r s}(t)=\log w_{\ell, r s}(t)-\Delta_{r s}(t), \quad t=1980,1990
$$

where $\log w_{\ell, m}(t)$ is the $\log$ wage of person $\ell$ in skill group $r s$ in Census year $t$. 
There are obviously many possible ways of deflating the 1980 and 1990 wages to account for changes in the wage structure. The age/education deflator provides a particularly simple method. It is well known, however, that wage inequality increased even within schooling and experience cells. The deflated wages in equation (2), therefore, do not fully account for the changes in the wage structure observed during the period. To account for these within-group changes in wage inequality, LaLonde and Topel (1992) have suggested using a deflator based on an immigrant's ranking in the native wage distribution. In particular, we can use the native samples in the 1970,1980 , and 1990 Censuses to calculate the wage growth observed in each percentile of the wage distribution. We can then define $\Delta_{p}(t)$ to be the log wage growth observed by native workers in the $p^{\text {th }}$ percentile between 1970 and year $t(t=1980,1990){ }^{11}$

Suppose that an immigrant's wage in 1980 or 1990 places him in the $p^{\text {th }}$ percentile of the native wage distribution. If we assume that immigrants and natives in the $p^{\text {th }}$ percentile are equally skilled, we can then use the percentile deflator $\Delta_{p}(t)$ to net out the impact of changes in the wage structure on the relative immigrant wage. Although the percentile deflator seems to incorporate more of the wage variation than the simpler deflator based on a worker's age and education, it also introduces subtle biases into the analysis. In particular, the assumption that

11 The deflator $\Delta_{p}(t)$ was calculated for each percentile of the native wage distribution between the 5 th and the 95th, with the two extreme percentiles containing all workers in the relevant tails of the distribution. Although native workers in higher percentiles of the wage distribution typically exhibited faster wage growth between 1970 and 1990 , the Census data indicate that workers at the extreme tails of the distribution do not conform to this pattern. In general, workers below the 5th percentile had faster wage growth than other low-income workers, while workers above the 98 th percentile had slower wage growth than other high-income workers. I experimented with alternative measures of the wage growth experienced by workers at the very bottom of the wage distribution, and the results were generally quite similar. For example, if the 1990 wage of the bottom 5 percent of the workers is deflated by the wage growth experienced by workers in the 5 th percentile, the relative wage for immigrants who artived between 1985 and 1990 was -.338 ; for the 1980-1985 arrivals, -.286 ; for the 1975-1979 arrivals. - 171; for the 1970-1974 arrivals, -.085; for the 1965-1969 arrivals, .011; for the 1960-1964 arrivals, .076; for the 1950-1959 arrivals, .157; and for the pre-1950 arrivals, .207. 
natives and immigrants who place in the $p^{\text {th }}$ percentile are equally skilled is probably false. Newlyarrived immigrants might place badly in the native wage ranking not because they are unskilled, but because they have not yet acquired relevant information about the U.S. labor market (information which natives already have). After immigrants "find their way," they move up the wage distribution. In the end, therefore, an immigrant who initially places in the $p^{\text {th }}$ percentile might end up in the $(p+q)^{\text {th }}$ percentile. It would be incorrect, therefore, to use an immigrant's ranking in the native wage distribution during the initial learning period to assign him to a particular skill group.

It is clear, therefore, that neither of these deflators (i.e., the age/education deflator and the percentile deflator) can fully capture the "true" impact of changes in the wage structure on the relative immigrant wage. Nevertheless, the empirical analysis shows that the trends in the relative immigrant wage between 1970 and 1990 are essentially the same regardless of the deflator used. Table 3 reports the changes in the deflated relative wage of immigrants between 1970 and 1990 Even after accounting for the change in the wage structure, more recent immigrant cohorts have substantially lower relative wages than earlier cohorts (regardless of whether we look at the "raw" wage differentials or at the age-adjusted relative wage). For example, the most recent cohort in 1970 earned 18.1 percent less than natives at the time of arrival. If we use the deflator based on age-education skill groups, the most recent cohort in 1980 earned 29.0 percent less than natives, and the most recent cohort in 1990 eamed 34.9 percent less than natives. The increase in wage inequality, therefore, accounts for only 16.2 percent of the drop in the relative wage of successive immigrant cohorts between 1970 and 1990. Similarly, if we use the percentile deflator, the relative wage of the most recent cohort in 1980 declines to 30.3 percent, while that of the most 
TABLE 3. IMMIGRANT LOG WAGE, DEFLATED BY CHANGES IN WAGE STRUCTURE (Relative to Natives)

\begin{tabular}{|c|c|c|c|c|c|}
\hline \multirow[b]{2}{*}{ Variable/Group: } & \multirow[b]{2}{*}{$\underline{1970}$} & \multicolumn{2}{|c|}{ Age/Education Deflator } & \multicolumn{2}{|c|}{ Percentile Deflator } \\
\hline & & $\underline{1980}$ & $\underline{1990}$ & $\underline{1980}$ & $\underline{1990}$ \\
\hline \multicolumn{6}{|c|}{ Unadjusted Wage Differentials } \\
\hline All Immigrants & $\begin{array}{c}.0090 \\
(.0036)\end{array}$ & $\begin{array}{l}-.0986 \\
(.0023)\end{array}$ & $\begin{array}{l}-.1555 \\
(.0020)\end{array}$ & $\begin{array}{l}-.0902 \\
(.0022)\end{array}$ & $\begin{array}{l}-.1+93 \\
(.0019)\end{array}$ \\
\hline \multicolumn{6}{|l|}{ Cohort: } \\
\hline 1985-1989 Arrivals & $\cdots$ & - & $\begin{array}{l}-.3490 \\
(.0034)\end{array}$ & $\cdots$ & $\begin{array}{l}-.3482 \\
(.0032)\end{array}$ \\
\hline 1980-1984 Arrivals & - & - & $\begin{array}{l}-.2881 \\
(.0032)\end{array}$ & $\cdots$ & $\begin{array}{l}-.2925 \\
(.0032)\end{array}$ \\
\hline 1975-1979 Arrivals & - & $\begin{array}{l}-.2900 \\
(.0041)\end{array}$ & $\begin{array}{r}-.1718 \\
(.0035)\end{array}$ & $\begin{array}{l}-.3032 \\
(.0039)\end{array}$ & $\begin{array}{l}-.1749 \\
(.0033)\end{array}$ \\
\hline 1970-1974 Arrivals & - & $\begin{array}{l}. .1926 \\
(.0042)\end{array}$ & $\begin{array}{c}-.0919 \\
(.0039)\end{array}$ & $\begin{array}{l}-.1968 \\
(.0039)\end{array}$ & $\begin{array}{l}-.0868 \\
(.0037)\end{array}$ \\
\hline 1965-1969 Arrivals & $\begin{array}{c}-.1811 \\
(.0075)\end{array}$ & $\begin{array}{c}-.0858 \\
(.0045)\end{array}$ & $\begin{array}{l}. .0023 \\
(.0044)\end{array}$ & $\begin{array}{l}-.0751 \\
(.0042)\end{array}$ & $\begin{array}{c}.0106 \\
(.0042)\end{array}$ \\
\hline 1960-1964 Arrivals & $\begin{array}{r}-.0446 \\
(.0082)\end{array}$ & $\begin{array}{l}-.0096 \\
(.0051)\end{array}$ & $\begin{array}{c}.0582 \\
(.0051)\end{array}$ & $\begin{array}{l}.0021 \\
(.0048)\end{array}$ & $\begin{array}{l}.0764 \\
(.0049)\end{array}$ \\
\hline 1950-1959 Arrivals & $\begin{array}{c}.0548 \\
(.0063)\end{array}$ & $\begin{array}{l}.0387 \\
(.0041)\end{array}$ & $\begin{array}{l}.1227 \\
(.0049)\end{array}$ & $\begin{array}{l}.0526 \\
(.0039)\end{array}$ & $\begin{array}{l}.1582 \\
(.0047)\end{array}$ \\
\hline Pre-1950 Arrivals & $\begin{array}{l}.0980 \\
(.0055)\end{array}$ & $\begin{array}{l}.0461 \\
(.0052)\end{array}$ & $\begin{array}{l}.1483 \\
(.0090)\end{array}$ & $\begin{array}{c}.0969 \\
(.0049)\end{array}$ & $\begin{array}{l}.2084 \\
(.0086)\end{array}$ \\
\hline \multicolumn{6}{|c|}{ Age-Adjusted Wage Differentials } \\
\hline All Immigrants & $\begin{array}{l}.0006 \\
(.0059)\end{array}$ & $\begin{array}{l}-.1040 \\
(.0035)\end{array}$ & $\begin{array}{l}-.1677 \\
(.0029)\end{array}$ & $\begin{array}{l}. .0991 \\
(.0033)\end{array}$ & $\begin{array}{l}-.1536 \\
(.0027)\end{array}$ \\
\hline \multicolumn{6}{|l|}{ Cohort: } \\
\hline 1985-1989 Arrivals & - & $\cdots$ & $\begin{array}{l}-.3542 \\
(.0041)\end{array}$ & $\cdots$ & $\begin{array}{l}-.3196 \\
(.0039)\end{array}$ \\
\hline 1980-1984 Arrivals & - & - & $\begin{array}{c}-.2989 \\
(.0039)\end{array}$ & $\cdots$ & $\begin{array}{l}-.2724 \\
(.0037)\end{array}$ \\
\hline 1975-1979 Arrivals & - & $\begin{array}{l}.2880 \\
(.0050)\end{array}$ & $\begin{array}{l}-.1977 \\
(.0040)\end{array}$ & $\begin{array}{l}-.2756 \\
(.0047)\end{array}$ & $\begin{array}{l}-.1804 \\
(.0038)\end{array}$ \\
\hline 1970-1974 Arrivals & - & $\begin{array}{l}-.2012 \\
(.0049)\end{array}$ & $\begin{array}{l}-.1258 \\
(.0043)\end{array}$ & $\begin{array}{l}-.1876 \\
(.0046)\end{array}$ & $\begin{array}{c}-.1198 \\
(.0041)\end{array}$ \\
\hline 1965-1969 Arrivals & $\begin{array}{l}-.1856 \\
(.0081)\end{array}$ & $\begin{array}{l}-.1038 \\
(.0051)\end{array}$ & $\begin{array}{l}-.0221 \\
(.0049)\end{array}$ & $\begin{array}{l}.09+9 \\
(.0047)\end{array}$ & $\begin{array}{l}-.0224 \\
(.0046)\end{array}$ \\
\hline 1960-1964 Arrivals & $\begin{array}{l}-.0555 \\
(.0086)\end{array}$ & $\begin{array}{l}-.0232 \\
(.0056)\end{array}$ & $\begin{array}{l}.0417 \\
(.0055)\end{array}$ & $\begin{array}{l}-.0233 \\
(.0053)\end{array}$ & $\begin{array}{l}.0382 \\
(.0052)\end{array}$ \\
\hline 1950-1959 Arrivals & $\begin{array}{l}.0425 \\
(.0067)\end{array}$ & $\begin{array}{c}.0461 \\
(.0050)\end{array}$ & $\begin{array}{c}.1116 \\
(.0056)\end{array}$ & $\begin{array}{c}.0386 \\
(.0047)\end{array}$ & $\begin{array}{l}.1007 \\
(.0052)\end{array}$ \\
\hline Pre-1950 Arrivals & $\begin{array}{l}.1309 \\
(.0075)\end{array}$ & $\begin{array}{c}.0936 \\
(.0064)\end{array}$ & $\begin{array}{c}.1681 \\
(.0096)\end{array}$ & $\begin{array}{c}.0844 \\
(.0061)\end{array}$ & $\begin{array}{c}.1556 \\
(.0090)\end{array}$ \\
\hline
\end{tabular}

Notes Standard errors are reported in parentheses. The age-adjusted wage differentials are calculated from a regression estimated in each Census cross-section which includes a cubic term in the worker's age and interacts the age variables with an inmigrant dummy. The log wage differentiais are then evaluated at the age of 40 . 
recent cohort in 1990 declines to 34.8 percent. Again, the change in the wage structure accounts for only 16.6 percent of the decline in the immigrant relative wage between 1970 and 1990 .

Finally, the improvement in the relative wage of an immigrant cohort over time may not represent true wage convergence because the sample composition of a particular immigrant cohort is changing systematically across Censuses. It is widely believed that as many as one-third of the immigrants in the United States eventually return to their origin countries. Suppose that the return migrants are disproportionately composed of workers with lower than average wages. The intercensal tracking of a particular immigrant cohort would then indicate an improvement in relative wages even if no wage convergence is taking place. Alternatively, if the retum migrants are the "successes" the rate of wage convergence would be underestimated. Because of data limitations, the selection mechanism generating the return migration flow has not been extensively studied. ${ }^{12}$ As a result, little can be done to net out the bias introduced by nonrandom return migration on the estimated rate of wage convergence.

The sample composition of a particular immigrant cohort will also change over time because the sample of working-aged immigrants in later Censuses includes a larger number of immigrants who migrated as children (Friedberg, 1992; Smith, 1992). It is unlikely that these "immigrant children" experienced the same adaptation process as immigrants who arrived in the

\footnotetext{
12 An important exception is the work of Ramos (1992), who analyzes the return migration decisions of Puerto Ricans living in the United States. Because Puerto Rico is a U.S. possession. the joint study of the Puerto Rican and the U.S. Censuses provides valuable information on the characteristics of Puerto Ricans in the United States versus those of Puerto Ricans who remained in their homeland. as well as on the characteristics of Puerto Ricans who returned to Puerto Rico after living in the United States for a brief period. Ramos finds that Puerto Rican "immigrants" in the United States are relatively unskilled. but that the return migrants are relatively more skilled than the typical immigrant. Borjas and Bratsberg (1994) provide a detailed discussion of the determinants and consequences of return migration by combining microdata drawn from the 1980 Census with estimated rates of return migration for a number of national origin groups.
} 
United States as adults. The inclusion of these immigrant children in the later Censuses will bias the estimated rate of wage convergence upward because the wage determination process experienced by these children is more likely to resemble that faced by native workers. As a result, it is not sufficient to adjust for differences in the age composition between immigrants and natives as of the time of the Census (as done in the construction of the age-adjusted relative wage reported earlier). Instead, it is preferable to track a specific immigrant cohort, defined in terms of both year-of-migration and age-at-arrival, across the various Censuses.

Table 4 reports the relative wage of immigrants in a particular cohort and age-at-arrival group relative to natives in the same age group (so that, for example, immigrants aged 25-34 in 1970 are compared to natives aged $25-34$ in 1970 , to natives aged $35-44$ in 1980 , and to natives aged $45-54$ in 1990). The data indicate that a large part of the wage convergence reported in Tables 1 and 3 vanishes once we control for age-at-migration. Consider, for example, the group of immigrants who arrived between 1965 and 1969 and who were $25-74$ years old in 1970. Their relative wage in 1970 was -12.8 percent. By 1980 , the relative wage of this group had increased to -6.1 percent, and by 1990 the relative wage was -2.6 percent. Over a 20 -year period. therefore, the relative wage of this cohort increased by only 10 percentage points, in contrast to the 16 percentage point increase in the age-adjusted wage differential and the 20 point increase in the unadjusted differential.

The remaining rows in Table 4 reveal practically the same pattern for all immigrant cohorts. This result is important because it suggests that more recent immigrant cohorts have not experienced faster wage growth despite their lower initial starting positions. ${ }^{13}$ In particular. Table

${ }_{13}$ Duleep and Regets (1992) use correlations from the 1980 Census to argue that the relatively low initial eamings of the immigrants who arrived in the late 1970s did not represent their true "quality. 
TABLE 4. TRACKNG AGE COHORTS ACROSS CENSUSES (Immigrant Log Wage Relative to Natives)

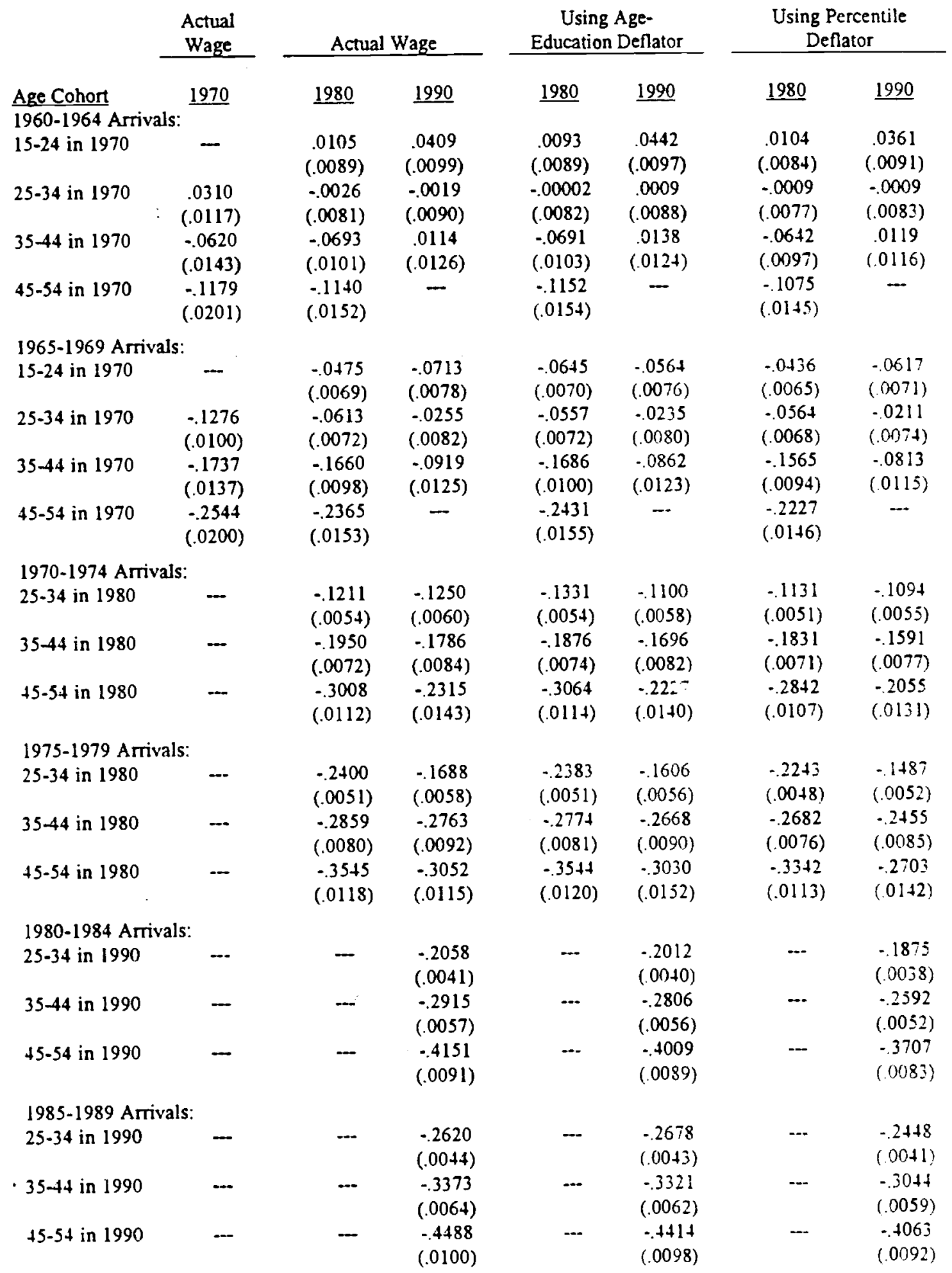

Note: Standard errors are reported in parentheses. 
4 indicates that during their first decade in the United States the immigrants who arrived during the 1970s experienced roughly the same wage growth as the immigrants who arrived during the 1960s. For example, the relative wage of the immigrants who arrived between 1975 and 1979 and who were aged $25-34$ in 1980 grew from -24.0 to -16.9 percent during their first ten years in the country, an increase of only 7 percentage points. This increase is of the same order of magnitude as the wage growth experienced by immigrants aged 25-34 who arrived between 1965 and 1969 (their relative wage grew from -12.8 percent to -6.1 percent between 1970 and 1980).

The descriptive statistics presented in this section, therefore, yield three findings. The relative wage of immigrants who entered the United States in the 1980 s was lower than the relative wage of earlier immigrant waves, continuing a trend that has been observed throughout the entire postwar period (Borjas, 1992). ${ }^{14}$ Second, the changes in the wage structure observed in the 1980s were not sufficiently large to generate the relative declire in immigrant wages, so that much of this decline is directly attributable to a relative decline in immigrant skills. Finally, the process of "assimilation" reduces the wage gap between immigrants and natives by about 10 percentage points during the first 20 years after arrival, regardless of the immigrant's initial position in the wage distribution.

because they would tend to have faster wage growth than earlier immigrants. The post-1980 experience of this cohort contradicts their hypothesis.

14 The trends suggested by the 1990 Census differ somewhat from those presented by Funkhouser and Trejo (1995) who use CPS data to determine if immigrant skills declined during the 1980s. The CPS data indicate that the decline in skills was reversed slightly by the late $1980 \mathrm{~s}$. It is important to note. however, that the Funkhouser-Trejo conclusions are based on relatively small samples of immigrants (the typical sample of recent immigrants has only about 350 observations), and many of the differences reported in their paper are statistically insignificant. More importantly, the national origin composition of immigrant cohorts is extremely unstable across surveys. For instance, 21 percent of the 1982-1984 immigrant cohort in the June 1988 CPS is of Mexican origin, while the respective statistic for the same cohort in the November 1989 CPS is 37 percent. These differences suggest that the change in the relative immigrant wage across the Current Population Surveys provides unreliable measures of both cohort effects and of the rate of wage convergence. 


\section{Regression Analysis}

Although the descriptive data presented in the previous section contains many of the key results of the paper, it is instructive to conduct a more formal analysis of the determinants of immigrant earnings. Suppose that we pool all the data in the 1970,1980 and 1990 Censuses. The simplest version of the regression model used in the study is given by:

$$
\begin{aligned}
& \log w_{i j}=X_{j} \phi_{i}+\delta_{i} A_{j}+\alpha y_{j}+\sum_{t} \beta_{l} C_{t}+\gamma_{i}^{0} \pi_{j}^{0}+\gamma_{i}^{1} \pi_{j}^{1}+\varepsilon_{i j}, \\
& \log w_{n \ell}=X_{\ell} \phi_{n}+\delta_{n} A_{l}+\gamma_{n}^{0} \pi_{l}^{0}+\gamma_{n}^{1} \pi_{l}^{1}+\varepsilon_{n \ell},
\end{aligned}
$$

where $w_{i j}$ gives the wage of immigrant person $j$; $w_{n \ell}$ gives the earnings of native person $\ell, X$ gives a vector of socioeconomic characteristics (described below); $A$ gives ine worker's age as of the time of the Census; $y_{j}$ gives the number of years that the immigrant has resided in the Linited States; $C$ is a vector of dummy variables indicating the calendar year in which the migration occurred; $\pi^{0}$ is a dummy variable indicating if the observation was drawn from the 1970 Census; and $\pi^{1}$ is a dummy variable indicating if the observation was drawn from the 1980 Census. ${ }^{\text {s }}$

15 The number of years-since-migration is given by the midpoint of the interval reporting the person's calendar year of arrival. For example, in the 1990 Census some persons are reported 10 have migrated between 1985 and 1986; the corresponding years-since-migration would then be 4.5 years. The openended interval in the 1970 Census refers to immigrants who arrived prior 101915 : these workers are assumed to have been in the United States for 60 years. The open-ended interval in the 1980 Census refers to immigrants who arrived prior 1950; these workers are assigned a value of 40 years. Finally. the open-ended interval in the 1990 Census refers to immigrants who arrived prior to 1950. and these workers are assigned a value of 50 years. 
The coefficient vectors $\gamma_{i}$ and $\gamma_{n}$ give the period effects for immigrants and natives, respectively. The coefficient $\delta_{n}$ gives the aging effect for natives; the rate at which native earnings increase over the life cycle. The respective aging effect for immigrants is given by the sum of coefficients $\left(\delta_{i}+\alpha\right)$. The age-earnings profiles of immigrants and natives converge if $\left(\delta_{1}+\alpha\right)>$ $\delta_{n}$. The vector of dummy variables $C$ indicate the cohort of arrival. As before, the cohorts used in the regression are: 1985-1989 arrivals; 1980-1984 arrivals; $1975-1979$ arrivals; 1970-1974 arrivals; 1965-1969 arrivals; 1960-1964 arrivals; 1950-1959 anrivals; and pre-1950 arrivals. The vector of coefficients $\beta$ thus captures the cohort effects, the differences in entry wages across immigrant cohorts.

It is well known that the parameters of the regression model in equations ( 3 ) and (4) are not identified. In order to separately identify the two period effects, the aging effects. and the cohort effects, a restriction must be imposed on the model. One possiule restriction is that the period effects are the same for immigrants and natives. In particular:

$$
\gamma_{n}^{0}=\gamma_{i}^{0}, \text { and } \gamma_{n}^{1}=\gamma_{1}^{1} \text {. }
$$

so that the relative wage of immigrants and natives is independent of secular changes in the wage level.

Table 5 presents the basic set of regressions when the dependent variable is the log wage adjusted by the age/education deflator, while Table 6 presents an analogous set of regressions using the percentile deflator. The basic regression specification used in these tables is somewhat more general than the simpler model given in equations (3) and (4). In particular, the regressions include third-order polynomials in both age and years-since-migration. Further, the worker's age 
TABLE 5. REGRESSION USING POOLED 1970, 1980, AND 1990 CENSUSES (Dependent Variable = Log Wage Rate, Using Age/Education Deflator)

\begin{tabular}{|c|c|c|c|c|c|c|}
\hline Variable & (1) & (2) & (3) & (4) & (5) & $(6)$ \\
\hline \multirow[t]{2}{*}{ Intercept } &.$- \overline{6242}$ & -1.2220 & -.7085 & -1.1903 & -.6351 & -1.2453 \\
\hline & $(.0574)$ & $(.0540)$ & $(.0424)$ & $(.0402)$ & $(.0571)$ & $(.0537)$ \\
\hline \multirow[t]{2}{*}{ Age } & .1180 & .0942 & .1259 & .0941 & .1183 & .0948 \\
\hline & $(.0042)$ & $(.0040)$ & $(.0031)$ & $(.0029)$ & $(.0042)$ & $(.0040)$ \\
\hline \multirow{2}{*}{ Age $^{2}$} & -.0020 & -.0015 & -.0022 & -.0016 & -.0020 & -.0015 \\
\hline & $(.0001)$ & $(.0001)$ & $(.0001)$ & $(.0001)$ & $(.0001)$ & $(.0001)$ \\
\hline \multirow[t]{2}{*}{$\mathrm{Age}^{3} \times 10^{-4}$} & .1044 & .0735 & .1239 & .0802 & .1048 & .0744 \\
\hline & $(.0077)$ & $(.0073)$ & $(.0057)$ & $(.0054)$ & $(.0077)$ & $(.0072)$ \\
\hline \multirow[t]{2}{*}{ Imnigrant $(=1)$} & -.3471 & .1649 & -.1727 & .0901 & -.5495 & .2459 \\
\hline & $(.0847)$ & $(.0796)$ & $(.0060)$ & $(.0084)$ & $(.0964)$ & $(.0905)$ \\
\hline \multirow[t]{2}{*}{ Age $\times$ Immigrant } & .0113 & -.0065 & -- & $\cdots$ & .0293 & -.0067 \\
\hline & $(.0063)$ & $(.0059)$ & & & $(.0071)$ & $(.0067)$ \\
\hline \multirow[t]{2}{*}{$\mathrm{Age}^{2} \times$ Immigrant } & -.0005 & -.0001 & - & - & -.0009 & -.0001 \\
\hline & $(.0001)$ & $(.0001)$ & & & $(.0002)$ & $(.0002)$ \\
\hline \multirow{2}{*}{$\begin{array}{l}\left(\mathrm{Age}^{3} \times\right. \\
\quad \text { Immigrant }) \times 10^{-4}\end{array}$} & .0403 & .0125 & -- & $\ldots$ & .0720 & $.01+3$ \\
\hline & $(.0115)$ & $(.0108)$ & & & $(.0129)$ & $(.0121)$ \\
\hline \multirow{2}{*}{$\begin{array}{l}\text { Years-Since- } \\
\text { Migration }\end{array}$} & .0112 & .0186 & .0069 & .0135 & .0065 & .0184 \\
\hline & $(.0007)$ & $(.0007)$ & $(.0007)$ & $(.0007)$ & $(.0011)$ & $(.0011)$ \\
\hline \multirow{2}{*}{$\begin{array}{l}\text { Years-Since- } \\
\text { Migration) }\end{array}$} & -.0001 & -.0004 & -.0002 & -.0004 & .0003 & -.0002 \\
\hline & $(.0000)$ & $(.0000)$ & $(.0000)$ & $(.0000)$ & $(.0001)$ & $(.0001)$ \\
\hline \multirow{2}{*}{$\begin{array}{l}\text { (Years-Since- } \\
\text { Migration) } \\
\text { M }^{3} \times 10^{-4}\end{array}$} & .0038 & .0324 & .0159 & .0348 & -.0723 & .0076 \\
\hline & $(.0038)$ & $(.0036)$ & $(.0034)$ & $(.0035)$ & $(.0126)$ & $(.0119)$ \\
\hline \multirow[t]{2}{*}{ 1980-1984 Árivals } & .0003 & .0043 & .0015 & $.00+2$ & $.00+8$ & -.0038 \\
\hline & $(.0048)$ & $(.0047)$ & $(.0046)$ & $(.0046)$ & $(.0054)$ & $(.0053)$ \\
\hline \multirow[t]{2}{*}{ 1975-1979 Arrivals } & .0607 & .0594 & .0601 & .0592 & .0530 & .0449 \\
\hline & $(.0053)$ & $(.0054)$ & $(.0044)$ & $(.0053)$ & $(.0064)$ & $(.0068)$ \\
\hline \multirow[t]{2}{*}{ 1970-1974 Arrivals } & .0970 & .0952 & .0981 & .0938 & .0938 & .0861 \\
\hline & $(.0068)$ & $(.0070)$ & $(.0052)$ & $(.0069)$ & $(.0086)$ & $(.0093)$ \\
\hline \multirow[t]{2}{*}{ 1965-1969 Arrivals } & .1535 & .1130 & .1630 & .1106 & .1524 & .1112 \\
\hline & $(.0079)$ & $(.0083)$ & $(.0053)$ & $(.0081)$ & $(.0107)$ & $(.0117)$ \\
\hline \multirow[t]{2}{*}{ 1960-1964 Arrivals } & .2023 & .1366 & .2162 & .1339 & 2038 & .1405 \\
\hline & $(.0095)$ & $(.0100)$ & $(.0060)$ & $(.0097)$ & $(.0133)$ & $(.0145)$ \\
\hline \multirow[t]{2}{*}{ 1950-1959 Arrivals } & .2352 & .1602 & .2559 & .1576 & .2470 & .1756 \\
\hline & $(.0115)$ & $(.0122)$ & $(0065)$ & $(.0117)$ & $(.0171)$ & $(.0184)$ \\
\hline \multirow[t]{2}{*}{ Pre-1950 Arrivals } & .2355 & .1459 & .2727 & .1412 & 2677 & .1436 \\
\hline & $(.0163)$ & $(.0171)$ & $(.0085)$ & $(.0162)$ & $(.0256)$ & $(.0267)$ \\
\hline \multirow[t]{2}{*}{1970 Period Effect } & .0068 & .0248 & -.0045 & .0292 & .0154 & .0466 \\
\hline & $(.0081)$ & $(.0108)$ & $(.0074)$ & $(.0108)$ & $(.0084)$ & $(.0116)$ \\
\hline \multirow[t]{2}{*}{1980 Period Effect } & .0480 & -.0007 & .0458 & -.0171 & .0705 & .0357 \\
\hline & $(.0061)$ & $(.0081)$ & $(.0059)$ & $(.0080)$ & $(.0066)$ & $(.009 \mathrm{i})$ \\
\hline \multirow[t]{2}{*}{ Years of Schooling } & -. & .0604 & $\ldots$ & .0597 & -- & .0613 \\
\hline & & $(.0004)$ & & $(.0004)$ & & $(.0004)$ \\
\hline \multirow{2}{*}{$\begin{array}{l}\text { Education } x \\
\text { Immigrant }\end{array}$} & -- & -.0138 & $\cdots$ & -.0130 & $-\cdots$ & .0143 \\
\hline & & $(.0005)$ & & $(.0004)$ & & $(.0005)$ \\
\hline Age-at-Migration & -.. & -.. & -.0049 & -.0051 & $\ldots$ & $\ldots$ \\
\hline $\mathrm{R}^{2}$ & .048 & .162 & $\begin{array}{c}(.0001) \\
.0 \div 8\end{array}$ & $\begin{array}{l}(.0001) \\
.162\end{array}$ & .047 & 163 \\
\hline
\end{tabular}

Notes: Standard errors are reported in parentheses. The regressions in columns 14 have 920,700 observations. The regressions in Columns 5 and 6 use the pooled sample of natives and of immigrants who migrated as adults. and have 824,108 observations. Columns 2,4 , and 6 also include a variable indicating if the worker resides in a metropolitan area, as well as an interaction of that variable with immigration status. The regressions also interact the age, education, and metropolitan residence variables (when appropriate) with the period effects. The reported age and education coefficients are those obtained in the 1990 Census. 
TABLE 6. REGRESSION USING POOLED 1970, 1980, AND 1990 CENSUSES (Dependent Variable $=$ Log Wage Rate, Using Percentile Deflator)

\begin{tabular}{|c|c|c|c|c|c|c|}
\hline Variable & (1) & (2) & (3) & (4) & (5) & $6)$ \\
\hline \multirow{2}{*}{ Intercept } &.$- \overline{9122}$ & -1.5717 & -1.0012 & -1.5560 & -.9218 & -1.5981 \\
\hline & $(.0547)$ & $(.0513)$ & $(.0404)$ & $(.0382)$ & $(.0545)$ & $(.0511)$ \\
\hline \multirow[t]{2}{*}{ Age } & .1185 & .0962 & .1268 & .0977 & .1188 & .0968 \\
\hline & $(.0040)$ & $(.0038)$ & $(.0030)$ & $(.0028)$ & $(.0040)$ & $(.0038)$ \\
\hline \multirow[t]{2}{*}{$\mathrm{Age}^{2}$} & -.0018 & -.0014 & -.0021 & -.0015 & -.0019 & -.0014 \\
\hline & $(.0001)$ & $(.0001)$ & $(.0001)$ & $(.0001)$ & $(.0001)$ & $(.0001)$ \\
\hline \multirow[t]{2}{*}{$\mathrm{Age}^{3} \times 10^{-4}$} & .0881 & .0600 & .1083 & .0690 & .0886 & .0611 \\
\hline & $(.0074)$ & $(.0069)$ & $(.0054)$ & $(.0051)$ & $(.0073)$ & $(.0069)$ \\
\hline \multirow[t]{2}{*}{ Immigrant $(=1)$} & -.3452 & .1437 & -.1580 & .1072 & .5571 & .2152 \\
\hline & $(.0807)$ & $(.0757)$ & $(.0057)$ & $(.0080)$ & $(.0920)$ & $(.086 !)$ \\
\hline \multirow[t]{2}{*}{ Age $\times$ Immigrant } & .0127 & -.0029 & - & - & .0312 & -.0028 \\
\hline & $(.0060)$ & $(.0056)$ & & & $(.0068)$ & $(.0064)$ \\
\hline \multirow[t]{2}{*}{ Age $^{2} \times$ Immigrant } & -.0005 & -.0001 & - & - & -.0009 & -.0002 \\
\hline & $(.0001)$ & $(.0001)$ & & & $(.0002)$ & $(.0002)$ \\
\hline \multirow{2}{*}{$\begin{array}{l}\left(\mathrm{Age}^{3} \times\right. \\
\quad \text { Immigrant }) \times 10^{-4}\end{array}$} & .0422 & .0173 & $\cdots$ & $\cdots$ & $07+9$ & .0195 \\
\hline & $(.0109)$ & $(.0102)$ & & & $(.0123)$ & $(.0115)$ \\
\hline \multirow{2}{*}{$\begin{array}{l}\text { Years-Since- } \\
\text { Migration }\end{array}$} & .0119 & .0208 & .0077 & .0163 & .0078 & .0213 \\
\hline & $(.0006)$ & $(.0006)$ & $(.0006)$ & $(.0006)$ & $(.0011)$ & $(.0010)$ \\
\hline \multirow{2}{*}{$\begin{array}{c}\text { Years-Since- } \\
\text { Migration) }\end{array}$} & -.0002 & -.0005 & -.0003 & -.0005 & .0002 & -.0004 \\
\hline & $(.0000)$ & $(.0000)$ & $(.0000)$ & $(.0000)$ & $(.0001)$ & $(.0001)$ \\
\hline \multirow{2}{*}{$\begin{array}{l}\text { (Years-Since- } \\
\text { Migration) }{ }^{3} \times 10^{-4}\end{array}$} & .0107 & .0390 & .0227 & .0400 & -.0562 & .0243 \\
\hline & $(.0036)$ & $(.0034)$ & $(.0033)$ & $(.0033)$ & $(.0120)$ & $(.0113)$ \\
\hline \multirow[t]{2}{*}{ 1980-1984 Arrivals } & -.0091 & .0109 & -.0069 & -.0121 & -.0046 & -.0207 \\
\hline & $(.0046)$ & $(.0044)$ & $(.0044)$ & $(.0044)$ & $(.0051)$ & $(.0050)$ \\
\hline \multirow[t]{2}{*}{ 1975-1979 Arrivals } & .0417 & .0276 & .0436 & .0254 & .0359 & .0108 \\
\hline & $(.0051)$ & $(.0051)$ & $(.0042)$ & $(.0051)$ & $(.0061)$ & $(.0065)$ \\
\hline \multirow[t]{2}{*}{ 1970-1974 Arrivals } & .0737 & .0507 & .0784 & .0458 & .0731 & .0389 \\
\hline & $(.0065)$ & $(.0067)$ & $(.0050)$ & $(.0065)$ & $(.0082)$ & $(.0088)$ \\
\hline \multirow[t]{2}{*}{ 1965-1969 Arrivals } & .1264 & .0629 & .1398 & .0549 & .1306 & .0622 \\
\hline & $(.0075)$ & $(.0079)$ & $(.0050)$ & $(.0077)$ & $(.0102)$ & $(.0112)$ \\
\hline \multirow[t]{2}{*}{ 1960-1964 Arrivals } & .1716 & .0799 & .1902 & .0700 & .1801 & .0854 \\
\hline & $(.0091)$ & $(.0095)$ & $(.0057)$ & $(.0092)$ & $(.0127)$ & $(.0138)$ \\
\hline \multirow[t]{2}{*}{ 1950-1959 Arrivals } & .2010 & .0962 & .2275 & .0838 & 2182 & .1095 \\
\hline & $(.0110)$ & $(.0116)$ & $(.0062)$ & $(.0111)$ & $(0163)$ & $(.0175)$ \\
\hline \multirow[t]{2}{*}{ Pre-1950 Arrivals } & .2063 & .0829 & .2512 & .0621 & 2481 & .0787 \\
\hline & $(.0156)$ & $(.0162)$ & $(.0081)$ & $(.0154)$ & $(.0244)$ & $(.0254)$ \\
\hline \multirow[t]{2}{*}{1970 Period Effect } & 3278 &.$\$ 012$ & .3148 & .4058 & .3336 & +233 \\
\hline & $(.0077)$ & $(.0103)$ & $(.0070)$ & $(.0103)$ & $(.0080)$ & $(.0111)$ \\
\hline \multirow[t]{2}{*}{1980 Period Effect } & .1137 & .2403 & .1104 & .2164 & 1349 & .2829 \\
\hline & $(.0058)$ & $(.0077)$ & $(.0056)$ & $(.0076)$ & $(.0063)$ & $(.0087)$ \\
\hline \multirow[t]{2}{*}{ Years of Schooling } & $\cdots$ & $.06+6$ & $\cdots$ & .0632 & $\cdots$ & .0656 \\
\hline & & $(.0004)$ & & $(.0004)$ & & $(.0004)$ \\
\hline \multirow{2}{*}{$\begin{array}{l}\text { Education } \times \\
\text { Immigrant }\end{array}$} & - & -.0154 & $\cdots$ & -.0136 & $\cdots$ & -.0161 \\
\hline & & $(.0005)$ & & $(.0004)$ & & $(.0005)$ \\
\hline Age-at-Migration & - & $\cdots$ & $-.00+5$ & -.0047 & $\cdots$ & $\cdots$ \\
\hline $\mathrm{R}^{2}$ & .071 & .186 & $\begin{array}{l}(.0001) \\
.071\end{array}$ & $\begin{array}{l}(.0001) \\
.186\end{array}$ & 068 & 186 \\
\hline
\end{tabular}

Notes: Standard errors are reported in parentheses. The regressions in columns $1-t$ have 920.700 obsenations The regressions in Columns 5 and 6 use the pooled sample of natives and of immigrants who migrated as adults, and have 824,108 observations. Columns 2,4 , and 6 also include a variable indicating if the worker resides in a and have 824,108 as well as an interaction of that variable with immigration status. The regressions also interact

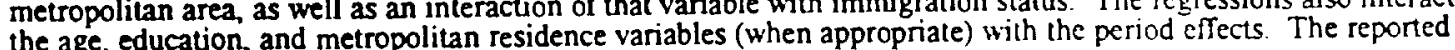
age and education coefficients are those obtained in the 1990 Census. 
and the variables in the vector $X$ are interacted with the period effects, so as to allow for different coefficients in each of the Censuses. The table reports the 1990 coefficients for these variables.

Column 1 in the tables reports the simplest specification of the regression model after imposing the restriction in equation (5). ${ }^{16}$ The regressions reported in this column do not include any variables in the standardizing vector $X$. The predicted age-earnings profiles, therefore: essentially "trace out" the raw data. The second column of the table includes both the worker's educational attainment and a dummy variable indicating if he lives in a metropolitan area

Because both age and years-since-migration are introduced as cubics, it is difficult to "read" the implications of the coefficients for the age/earnings profile of immigrants relative to that of natives directly from the tables. Instead, I summarize the regression results by predicting the wage path of an immigrant who enters the United States at age 20.17

Table 7 reports the predicted wage differential between immigrants and natives at the time of entry. Not surprisingly, the data indicate that there are sizable cohirt effects and that these cohort effects have greatly increased the initial wage disadvantage of immigrants. In the first column of the top panel, which does not control for educational attainment and which uses the log wage adjusted by the age/education deflator, immigrants who arrived in the late 1980 s earned about 27.2 percent less than natives at the time of entry; those who arrived in the late 1970 s

\footnotetext{
16 Even though the regressions use the deflated wages as dependent variables. they also include dummy: variables to further control for period effects. The deflators account for the impact of changes in the wage structure on the wage differences observed among prespecified groups (i.e., among the age/cducation cells or among the percentiles of the wage distribution). The period effects in the regressions effectively allow for secular changes in wage levels within these groups

17 When the regression includes educational attainment I use the mean cducational attainment in the 1990 immigrant sample, or 11.589 years, to conduct the simulation. The simulation also "turns on" the dummy variables indicating if the observation was drawn from the 1990 Census and if the worker resided in a metropolitan area.
} 
TABLE 7

PREDICTED WAGES OF IMMIGRANT COHORTS AT TIME OF ENTRY, RELATIVE TO NATIVES

(Assuming Immigrants Enter U.S. at Age 20)

\begin{tabular}{|c|c|c|c|c|c|c|}
\hline \multirow{2}{*}{\multicolumn{7}{|c|}{ Log Wage Rate, Using }} \\
\hline Age/Education Deflator & & & & & & \\
\hline 1985-1989 Arrivals & $\begin{array}{l}-.2716 \\
(.0106)\end{array}$ & $\begin{array}{c}-.1931 \\
(.0100)\end{array}$ & $\begin{array}{l}-.2704 \\
(.0042)\end{array}$ & $\begin{array}{l}-.2167 \\
(.0041)\end{array}$ & $\begin{array}{l}-.2674 \\
(.0119)\end{array}$ & $\begin{array}{l}-.1617 \\
(.0113)\end{array}$ \\
\hline 1980-1984 Arrivais & $\begin{array}{l}.2713 \\
(.0110)\end{array}$ & $\begin{array}{r}-.1888 \\
(.0106)\end{array}$ & $\begin{array}{l}-.2689 \\
(.0051)\end{array}$ & $\begin{array}{l}-.2126 \\
(.0054)\end{array}$ & $\begin{array}{l}-.2626 \\
(.0126)\end{array}$ & $\begin{array}{l}-1655 \\
(0121)\end{array}$ \\
\hline 1975-1979 Arrivals & $\begin{array}{l}-.2109 \\
(.0112)\end{array}$ & $\begin{array}{l}-.1337 \\
(.0110)\end{array}$ & $\begin{array}{l}-.2103 \\
(.0047)\end{array}$ & $\begin{array}{l}. .1576 \\
(.0060)\end{array}$ & $\begin{array}{l}-.2144 \\
(.0129)\end{array}$ & $\begin{array}{l}. .1168 \\
(.0121)\end{array}$ \\
\hline 1970-1974 Amivals & $\begin{array}{l}. .1746 \\
(.0120)\end{array}$ & $\begin{array}{l}-.0979 \\
(.0120)\end{array}$ & $\begin{array}{l}.1723 \\
(.0056)\end{array}$ & $\begin{array}{l}-.1230 \\
(.0076)\end{array}$ & $\begin{array}{l}-1735 \\
(.0141)\end{array}$ & $\begin{array}{l}.0756 \\
(.0144)\end{array}$ \\
\hline 1965-1969 Arrivals & $\begin{array}{l}-.1181 \\
(.0126)\end{array}$ & $\begin{array}{l}-.0800 \\
(.0128)\end{array}$ & $\begin{array}{l}-.1074 \\
(.0056)\end{array}$ & $\begin{array}{l}. .1062 \\
(.0087)\end{array}$ & $\begin{array}{l}-.1150 \\
(.0152)\end{array}$ & $\begin{array}{l}-.0504 \\
(.0159)\end{array}$ \\
\hline 1960-1964 Arrivals & $\begin{array}{l}-.0693 \\
(.0136)\end{array}$ & $\begin{array}{l}-.0565 \\
(.0140)\end{array}$ & $\begin{array}{l}-.0542 \\
(.0063)\end{array}$ & $\begin{array}{l}-.0829 \\
(.0103)\end{array}$ & $\begin{array}{l}-.0636 \\
(.0170)\end{array}$ & $\begin{array}{l}-.0212 \\
(.0180)\end{array}$ \\
\hline 1950-1959 Arrivals & $\begin{array}{l}-.0365 \\
(.0150)\end{array}$ & $\begin{array}{l}-.0329 \\
(.0156)\end{array}$ & $\begin{array}{l}-.0145 \\
(.0066)\end{array}$ & $\begin{array}{l}-.0592 \\
(.0123)\end{array}$ & $\begin{array}{l}-.0204 \\
(.0200)\end{array}$ & $\begin{array}{l}.0139 \\
(.0212)\end{array}$ \\
\hline \multicolumn{7}{|l|}{$\begin{array}{l}\text { Log Wage Rate, Using } \\
\text { Percentile Deflator }\end{array}$} \\
\hline 1985-1989 Arrivals & $\begin{array}{l}-.2506 \\
(.0101)\end{array}$ & $\begin{array}{l}-.1796 \\
(.0095)\end{array}$ & $\begin{array}{l}-.2477 \\
(.0040)\end{array}$ & $\begin{array}{l}-.15 .15 \\
(.0039)\end{array}$ & $\begin{array}{l}-.2497 \\
(.0114)\end{array}$ & $\begin{array}{l}-.1520 \\
(.0107)\end{array}$ \\
\hline 1980-1984 Arrivals & $\begin{array}{l}-.2596 \\
(.0105)\end{array}$ & $\begin{array}{l}-.1906 \\
(.0101)\end{array}$ & $\begin{array}{l}-.2546 \\
(.0049)\end{array}$ & $\begin{array}{l}-.2066 \\
(.0051)\end{array}$ & $\begin{array}{l}-.2543 \\
(.0120)\end{array}$ & $\begin{array}{l}-.1727 \\
(0115)\end{array}$ \\
\hline 1975-1979 Arrivals & $\begin{array}{l}-.2089 \\
(.0107)\end{array}$ & $\begin{array}{l}-.1520 \\
(.0105)\end{array}$ & $\begin{array}{l}-.2041 \\
(.0045)\end{array}$ & $\begin{array}{l}-.1691 \\
(.0057)\end{array}$ & $\begin{array}{l}-.2138 \\
(.0123)\end{array}$ & $\begin{array}{l}-.1413 \\
(.0122)\end{array}$ \\
\hline 1970-1974 Arrivals & $\begin{array}{l}-.1768 \\
(.0115)\end{array}$ & $\begin{array}{l}-.1289 \\
(.0114)\end{array}$ & $\begin{array}{l}. .1693 \\
(.0054)\end{array}$ & $\begin{array}{l}-.1486 \\
(.0072)\end{array}$ & $\begin{array}{l}-1766 \\
(.0134)\end{array}$ & $\begin{array}{l}-.1132 \\
(.0137)\end{array}$ \\
\hline 1965-1969 Arrivals & $\begin{array}{l}-.1242 \\
(.0120)\end{array}$ & $\begin{array}{l}-.1167 \\
(.0121)\end{array}$ & $\begin{array}{l}-.1080 \\
(.0053)\end{array}$ & $\begin{array}{l}-.1395 \\
(.0083)\end{array}$ & $\begin{array}{l}-.1192 \\
(.0145)\end{array}$ & $\begin{array}{l}-.0900 \\
(0152)\end{array}$ \\
\hline 1960-1964 Arrivals & $\begin{array}{l}-.0789 \\
(.0130)\end{array}$ & $\begin{array}{l}-.0997 \\
(.0133)\end{array}$ & $\begin{array}{l}-.0576 \\
(.0060)\end{array}$ & $\begin{array}{l}-.1244 \\
(.0098)\end{array}$ & $\begin{array}{l}-.0696 \\
(.0162)\end{array}$ & $\begin{array}{l}-.0667 \\
(.0171)\end{array}$ \\
\hline 1950-1959 Arrivals & $\begin{array}{l}-.0495 \\
(.0143)\end{array}$ & $\begin{array}{l}-.0834 \\
(.0148)\end{array}$ & $\begin{array}{l}-.0202 \\
(.0063)\end{array}$ & $\begin{array}{l}-.1106 \\
(.0117)\end{array}$ & $\begin{array}{l}-.0316 \\
(.0190)\end{array}$ & $\begin{array}{l}-.0426 \\
(.0202)\end{array}$ \\
\hline $\begin{array}{l}\text { Includes Educ } \\
\text { Includes Age- }\end{array}$ & No & Yes & No & Yes & No & Yes \\
\hline Includes A & No & No & Yes & Yes & No & No \\
\hline $\begin{array}{l}\text { Sample of Adult } \\
\text { Immigrants }\end{array}$ & - & -- & - & $\cdots$ & Yes & Yes \\
\hline
\end{tabular}

Notes: Standard errors are reported in parentheses. The regressions in columns 2,4 , and 6 also inciude a variable indicating if the worker resides in a metropolitan area. 
earned only about 21.1 percent less; and those who arrived in the late 1960 s earned about 11.8 percent less. The cohor differences, therefore, suggest a 9 percentage point drop in relative wages during the $1970 \mathrm{~s}$, and an additional 6 percentage point drop during the late $1980 \mathrm{~s} .{ }^{18}$

The qualitative nature of the results is not altered when the regression controls for a worker's educational attainment and a dummy variable indicating residence in a metropolitan area. Controlling for schooling differences among immigrant cohorts as well as between immigrants and natives attenuates the decline in relative wages among cohorts, as well as reduces the entry wage gap between immigrants and natives. After controlling for education, the entry wage of immigrants declined by "only" 5 percent during the 1970 s and by an additional 6 percent during the 1980s. Moreover, the adjusted entry wage gap for the $1985-89$ immigrant cohort is only 19.3 percent, as compared to 27.2 percent when the education gap between immigrants and natives is not accounted for.

The age-earnings profiles of immigrants (relative to those of natives) implied by the regressions are illustrated in the top two panels of Figures 1 and 2 . The simulations suggest that the relative wage of immigrants grows by about 10 percentage point during the first two decades after arrival, and that little relative wage growth occurs beyond that point. Because immigrants who arrived in the 1970 s and 1980 s start out at such a disadvantage, the wage of these recent cohorts eventually reaches a plateau that is 15 to 20 percent below that of natives. Controlling for educational attainment reduces the eventual wage gap to about 5 to 10 percentage points.

18 There are only slight differences in entry wages between the immigrants who arrived in the first half of the 1980s and those who arrived in the last half of the decade. It is too early to determine if the relative wage of immigrant cohorts indeed reached its trough in the late $1980 \mathrm{~s}$. or if this phenomenon is transitory. There was, for example, a sizable reduction in the number of relatively unskilled Indochinese refugees in the late 1980 s (relative to the early 1980s), as well as an increase in the number of skilled refugees originating in Eastem European countries. 
Figure 1. Predicted Relative Wage Profiles of Immigrants (Using Age/Education Deflator)

Immigrant Wage Profile

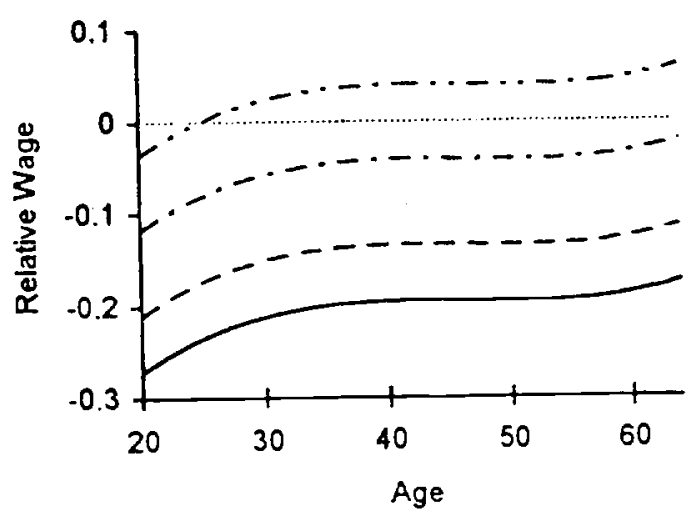

Adjusted for Age-At-Migration

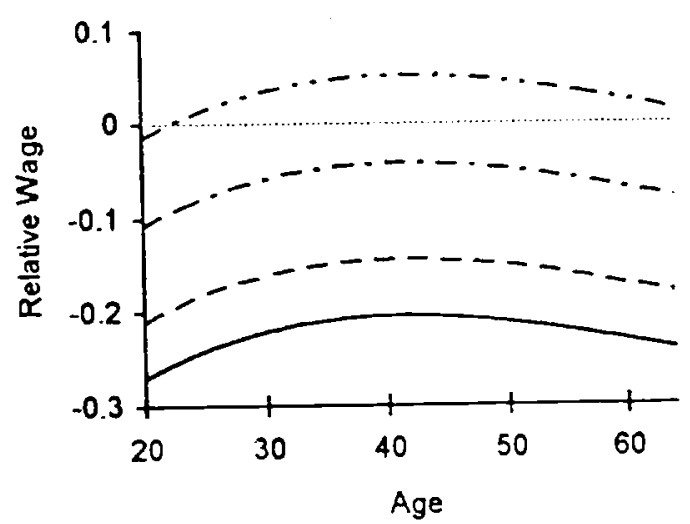

Using Sample of Adult Immigrants

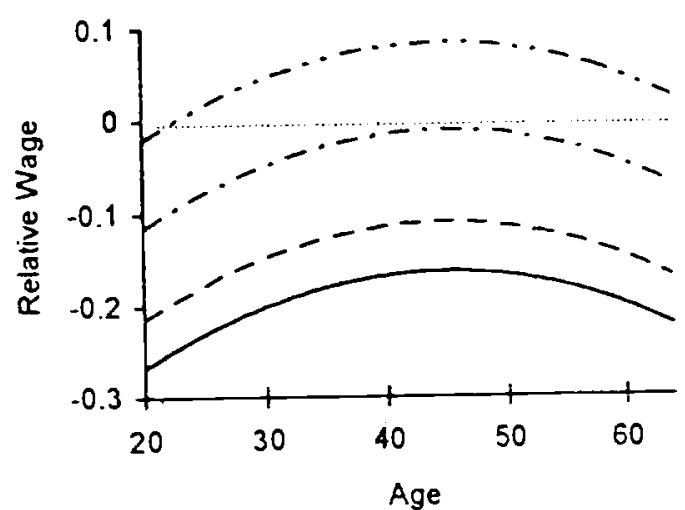

Adjusted for Education

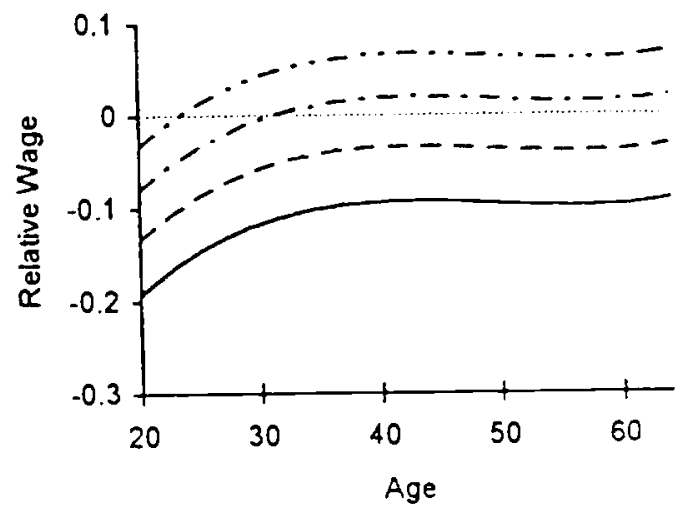

Adjusted for Education and Age-At-Migration

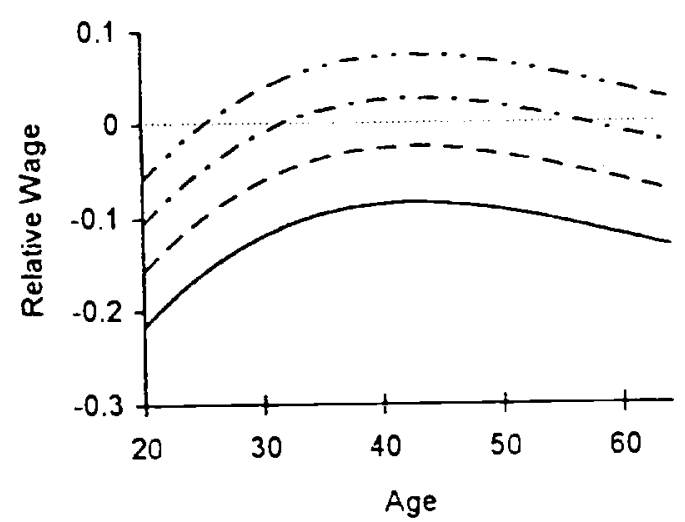

Using Sample of Adult Immigrants. and Adjusting for Education

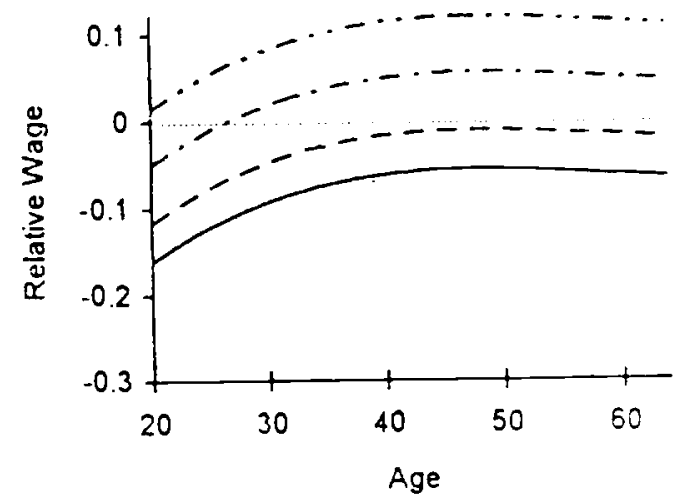

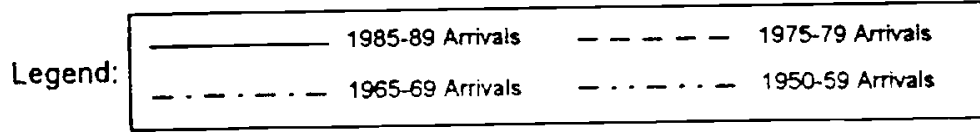


Figure 2. Predicted Relative Wage Profiles of Immigrants (Using Percentile Deflator)

Immigrant Wage Profile

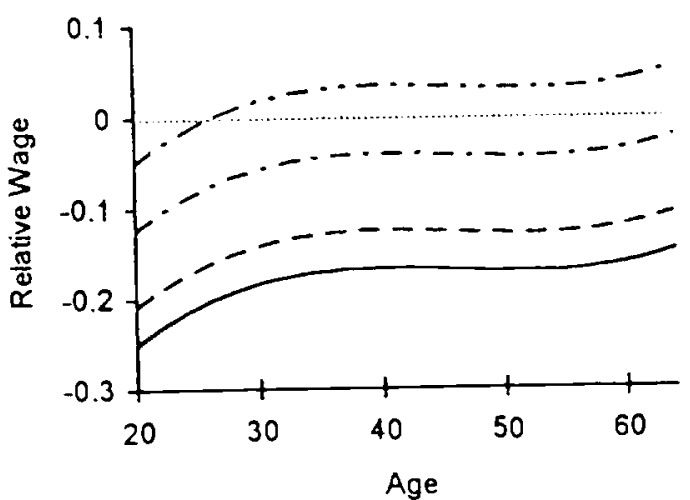

Adjusted for Age-At-Migration

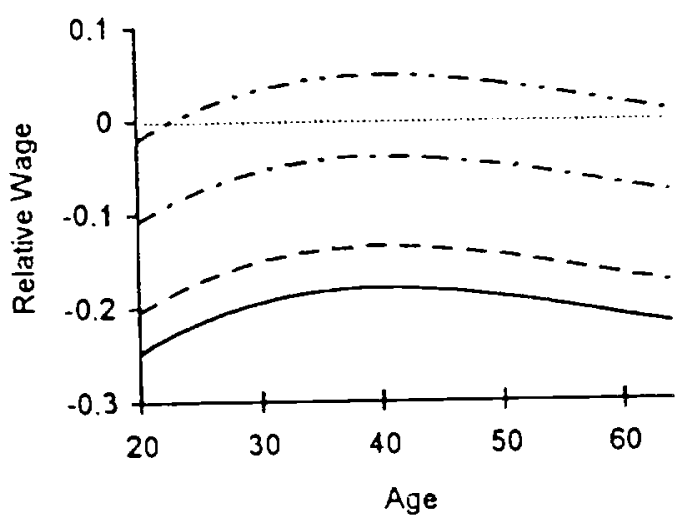

Using Sample of Adult Immigrants

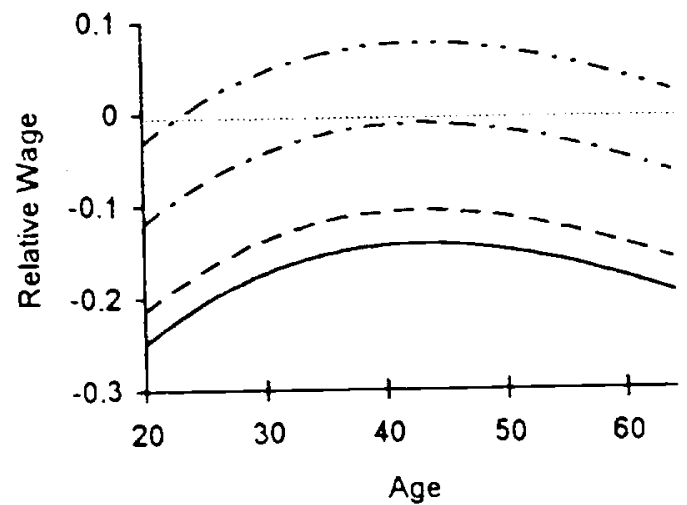

Adjusted for Education

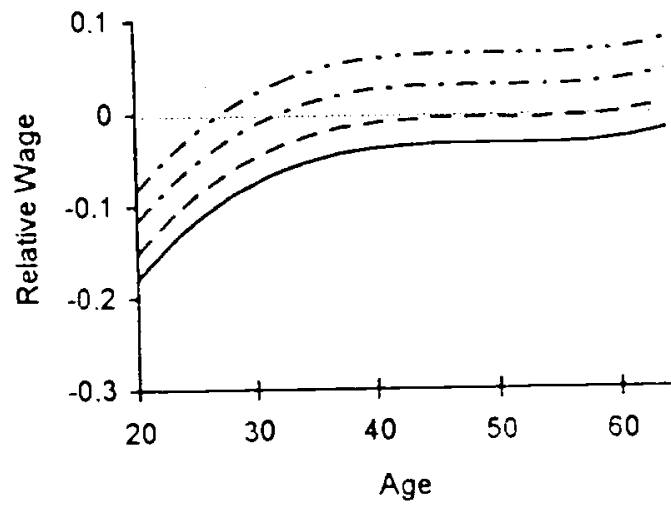

Adjusted for Education and Age-At-Migration

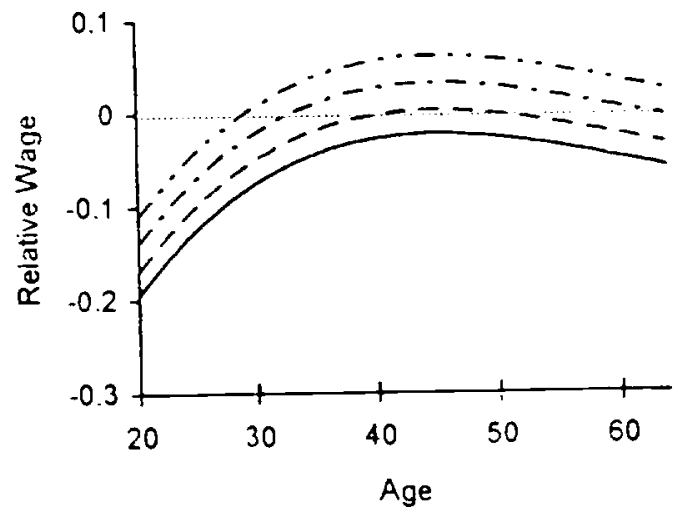

Using Sample of Adult Immigrants, and Adiusting for Education

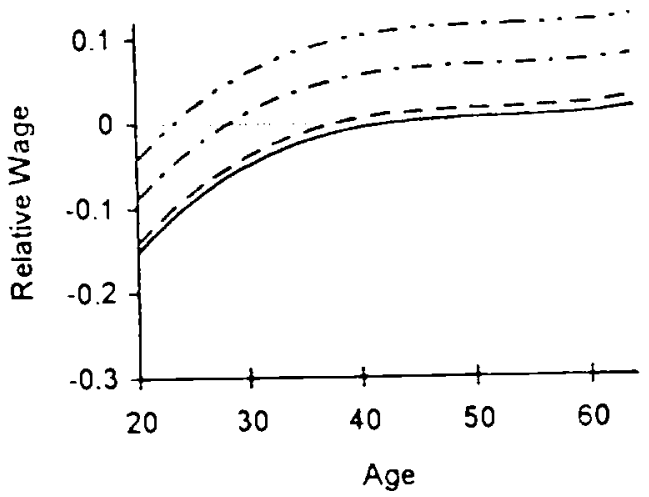

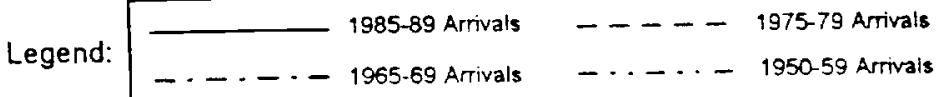


As suggested by the descriptive analysis, it is important to control for a worker's age-atmigration in order to better specify the wage convergence experienced by the immigrant population. A simple specification of this expanded model is given by:

$$
\begin{aligned}
& \log w_{i j}=X_{j} \phi_{i}+\delta_{i} A_{j}+\alpha y_{j}+\sum_{i} \beta_{l} C_{l}+\theta M_{j}+\gamma_{i}^{0} \pi_{j}^{0}+\gamma_{i}^{1} \pi_{j}^{1}+\varepsilon_{i j}, \\
& \log w_{n \ell}=X_{\ell} \phi_{n}+\delta_{n} A_{\ell}+\gamma_{n}^{0} \pi_{l}^{0}+\gamma_{n}^{1} \pi_{\ell}^{1}+\varepsilon_{n \ell},
\end{aligned}
$$

where $M_{j}$ gives the immigrant's age-at-migration. As before, the model in (6) and (7) cannot be identified unless the period effects are assumed to be the same for immigrants and natives. The introduction of age-at-migration as a variable, however, implies that the right-hand-side variables in equation (6) are still perfectly collinear. In particular, $M_{j} \equiv A_{j}-y_{j}$. It is impossible, therefore, to estimate the model unless an additional restriction is imposed on the data. One simple restriction, implicit in the work of Friedberg (1992) and Smith (1992), is that the coefficient of the age variable is the same for immigrants and natives. The estimation of the system in equations (6) and (7) thus requires the assumption that:

$$
\gamma_{n}^{0}=\gamma_{i}^{0}, \quad \gamma_{n}^{1}=\gamma_{i}^{1}, \text { and } \delta_{n}=\delta_{i}
$$

Although the assumption that the age coefficients are the same for immigrants and natives is obviously very restrictive, it is clear that some restriction must be imposed if age-at-migration has an independent effect on the wage determination process. 
Columns 3 and 4 of Tables 5 and 6 report the estimates of the model in equations (6) and (7). Age-at-migration has an important negative effect on immigrant earnings: A worker who migrates at age 30 has about 5 percent lower earnings than one who migrates at age 20 . The implications of the regression estimates for the entry wage differential are summarized in the respective columns of Table 7, and the implications for wage growth are illustrated in the middle two panels of Figures 1 and 2. The introduction of age-at-migration has little impact on the predicted relative entry wage and on the magnitude of the cohort effects. Immigrants who arived in the late 1980s still eam about 27 percent less than natives at the time of arrival, in contrast to an initial wage disadvantage of 21 percent for the $1975-79$ arrivals and of 10.7 percent for the 1965-69 arrivals. The estimated rates of wage convergence, however, are reduced when the regression controls for age-at-migration. Over a 20-year period, for example, the relative wage of immigrants increases by only about 7 percentage points.

An alternative way of controlling for age-at-migration reestimates the basic model in equations (1) and (2) using the subsample of immigrants who migrated to the United States as adults (which I define as migrating at age 18 or older). This approach effectively assumes that the age-at-migration effect simply differentiates persons who migrate as children (and are exposed to the U.S. schooling system) from those who migrate as adults.

The regression models estimated on the pooled samples of natives and adult immigrants are presented in the last two columns of Tables 5 and 6 . The corresponding wage differentials at the time of entry are reported in the last two columns of Table 7, and the predicted age-earnings profiles are illustrated in the bottom panel of Figures 1 and 2. It is clear that the resulis obtained from this exercise are generally similar to those obtained when I included age-at-migration as a variable in the regression. Regardless of how the age-at-migration "problem" is tackled, the data 
indicate that the relative wage of immigrants grows by less than 10 percentage points during the first 20 years after migration (when education is not held constant), with little relative wage growth occurring for the remaining of the life cycle.

It is important to stress than even though recent immigrants do not reach wage parity with natives, immigrants still gain from acquiring U.S.-specific labor market experience. The regression models in Tables 5 and 6 indicate that years-since-migration has an important positive impact on the immigrant wage. Suppose, for example, that we compare two "observationally equivalent" immigrants in terms of age and cohort quality, but one of the immigrants is a new arrival while the other has been in the United States for 10 years. The regression coefficients reported in column 1 of Table 5 suggest that the newly-arrived immigrant will earn about 10 percent less. The accumulation of U.S.-specific experience, therefore, has a numerically important effect on immigrant earnings; this correlation, however, is not strong enough for the relatively disadvantaged recent waves to "catch up" with native earnings.

\section{National Origin and Wage Convergence}

A great deal of evidence suggests that much of the decline in the relative skills of immigrant cohorts that occurred prior to 1980 can be attributed to changes in the national origin mix of immigrant flows, away from the "traditional" European countries and towards lessdeveloped countries (Borjas, 1992, LaLonde and Topel, 1992). There are sizable skill differentials among national origin groups in the United States, with immigrants originating in advanced, industrialized economies having more schooling and higher earnings than immigrants originating in poorer countries. 
Because more recent immigrant waves start off at such a disadvantage, it is not surprising that they cannot catch up to the earnings of the typical native American (who is mainly a white person of European ancestry). It is of some interest, therefore, to determine if the wage of these recent immigrant arrivals converges to the wage of U.S.-born workers who share the same ethnic background. I now analyze the trends in the relative wage of immigrants belonging to four large ethnic groups: Mexican immigrants, other Hispanic immigrants, Asian immigrants (excluding the Middle East), and "white" immigrants (defined as persons originating in Europe or Canada). The four native groups of "ethnically similar" background are: Mexican natives (i.e., U.S.-bom persons of Mexican ancestry); other Hispanic natives (all other U.S.-born persons who report being of Hispanic ancestry); Asian natives (i.e., non-Hispanic persons whose race is Asian); and white natives (i.e., non-Hispanic persons whose race is white). Table 8 summarizes the trends in the relative wage of immigrants in these groups. For simplicity, I only report the results obtained when using the log wage deflated by the age/education deflator. I conducted parallel analyses using both the actual wage as well as the percentile deflator and obtained similar findings.

There are striking differences in the trends in relative wages across the various groups. It is evident, for example, that the relative wage of Mexican immigrants has declined even relative to Mexican natives. In 1970, the typical Mexican immigrant who had just arrived in the United States earned 34.2 percent less than the typical Mexican native. By 1980, this gap had increased to 43.7 percent, and by 1990 it had widened further to 49.7 percent. In addition, tracking a specific cohort across the Censuses suggests that Mexican immigrants experience a 20-percentage point increase in relative wages during the first two decades in the United States. Note, however, that this comparison does not hold the person's age-at-migration constant 
TABLE 8. LOG WAGE OF MMMGRANTS BY NATTONAL ORIGN, RELATTVE TO NATTVES OF OWN ETHNICITY

(Using Age/Education Deflator)

\begin{tabular}{|c|c|c|c|c|c|c|c|c|c|c|c|c|}
\hline \multirow[b]{2}{*}{ Cohort } & \multicolumn{3}{|c|}{ Mexican } & \multicolumn{3}{|c|}{ Other Hispanic } & \multicolumn{3}{|c|}{ Asian } & \multicolumn{3}{|c|}{ White } \\
\hline & 1970 & $\underline{1980}$ & 1990 & $\underline{1970}$ & $\underline{1980}$ & 1990 & $\underline{1970}$ & $\underline{1980}$ & 1990 & 1970 & 1980 & 1990 \\
\hline All Immigrants & -.133 & -.210 & -.267 & -.010 & -.040 & -.137 & -.135 & -.126 &. .179 & .076 & .039 & .109 \\
\hline & $(.020)$ & $(.011)$ & $(.008)$ & $(.019)$ & $(.014)$ & $(.012)$ & $(.041)$ & $(.021)$ & $(.018)$ & $(.003)$ & $(.003)$ & $(.003)$ \\
\hline 1985-1989 Arrivals & - & 一 & -.491 & 一 & - & -.380 & - & 一 & -375 & - & - & -.008 \\
\hline & & & $(.010)$ & & & $(.013)$ & & & $(.019)$ & & & $(.007)$ \\
\hline 1980-1984 Arrivals & - & - & $\begin{array}{l}-.371 \\
(.009)\end{array}$ & - & - & $\begin{array}{l}-.267 \\
(.012)\end{array}$ & 一 & $\rightarrow$ & $\begin{array}{l}-.296 \\
(.019)\end{array}$ & - & - & $\begin{array}{l}.078 \\
(.009)\end{array}$ \\
\hline 1975-1979 Arrivals & 一 & $\begin{array}{l}-.437 \\
(.013)\end{array}$ & $\begin{array}{c}-.257 \\
(.009)\end{array}$ & - & $\begin{array}{l}-.262 \\
(.017)\end{array}$ & $\begin{array}{c}-.117 \\
(.014)\end{array}$ & - & $\begin{array}{c}-.319 \\
(.022)\end{array}$ & $\begin{array}{c}-.117 \\
(.019)\end{array}$ & - & $\begin{array}{l}-.039 \\
(.008)\end{array}$ & $\begin{array}{c}.105 \\
(.009)\end{array}$ \\
\hline 1970-1974 Arrivals & - & $\begin{array}{l}-.240 \\
(.012)\end{array}$ & $\begin{array}{l}-.172 \\
(.010)\end{array}$ & - & $\begin{array}{c}-.129 \\
(.016)\end{array}$ & $\begin{array}{l}-.024 \\
(.014)\end{array}$ & - & $\begin{array}{l}-.063 \\
(.022)\end{array}$ & $\begin{array}{c}.043 \\
(.020)\end{array}$ & - & $\begin{array}{l}-.096 \\
(.009)\end{array}$ & $\begin{array}{c}.070 \\
(.009)\end{array}$ \\
\hline 1965-1969 Arrivals & $\begin{array}{l}-.342 \\
(.028)\end{array}$ & $\begin{array}{l}-.151 \\
(.014)\end{array}$ & $\begin{array}{l}-.106 \\
(.011)\end{array}$ & $\begin{array}{l}-.191 \\
(.022)\end{array}$ & $\begin{array}{l}-.065 \\
(.016)\end{array}$ & $\begin{array}{c}.009 \\
(.014)\end{array}$ & $\begin{array}{l}-.210 \\
(.043)\end{array}$ & $\begin{array}{c}.060 \\
(.023)\end{array}$ & $\begin{array}{c}.091 \\
(.021)\end{array}$ & $\begin{array}{c}.063 \\
(.008)\end{array}$ & $\begin{array}{c}.001 \\
(.008)\end{array}$ & $\begin{array}{c}.111 \\
(.008)\end{array}$ \\
\hline 1960-1964 Arrivals & $\begin{array}{l}-.148 \\
(.027)\end{array}$ & $\begin{array}{l}-.111 \\
(.015)\end{array}$ & $\begin{array}{l}-.057 \\
(.013)\end{array}$ & $\begin{array}{c}.049 \\
(.022)\end{array}$ & $\begin{array}{c}.120 \\
(.016)\end{array}$ & $\begin{array}{c}.184 \\
(.015)\end{array}$ & $\begin{array}{l}-.042 \\
(.047)\end{array}$ & $\begin{array}{c}.115 \\
(.026)\end{array}$ & $\begin{array}{c}.132 \\
(.024)\end{array}$ & $\begin{array}{c}.031 \\
(.008)\end{array}$ & $\begin{array}{c}.067 \\
(.008)\end{array}$ & $\begin{array}{c}.119 \\
(.008)\end{array}$ \\
\hline 1950-1959 Arrivals & $\begin{array}{c}-.072 \\
(.024)\end{array}$ & $\begin{array}{l}-.032 \\
(.014)\end{array}$ & $\begin{array}{l}-.031 \\
(.013)\end{array}$ & $\begin{array}{c}.113 \\
(.026)\end{array}$ & $\begin{array}{c}.112 \\
(.019)\end{array}$ & $\begin{array}{c}.177 \\
(.019)\end{array}$ & $\begin{array}{l}-.008 \\
(.048)\end{array}$ & $\begin{array}{c}.054 \\
(.026)\end{array}$ & $\begin{array}{c}.102 \\
(.025)\end{array}$ & $\begin{array}{c}-.082 \\
(.005)\end{array}$ & $\begin{array}{c}.070 \\
(.005)\end{array}$ & $\begin{array}{l}.168 \\
(.006)\end{array}$ \\
\hline Pre-1950 Arrivals & $\begin{array}{l}-.073 \\
(.024)\end{array}$ & $\begin{array}{l}-.089 \\
(.018)\end{array}$ & $\begin{array}{l}-.093 \\
(.023)\end{array}$ & $\begin{array}{l}.238 \\
(.031)\end{array}$ & $\begin{array}{l}.238 \\
(.030)\end{array}$ & $\begin{array}{c}.166 \\
(.041)\end{array}$ & $\begin{array}{l}-.173 \\
(.044)\end{array}$ & $\begin{array}{l}-.111 \\
(.029)\end{array}$ & $\begin{array}{l}-.025 \\
(.041)\end{array}$ & $\begin{array}{c}.122 \\
(.004)\end{array}$ & $\begin{array}{c}100 \\
(.006)\end{array}$ & $\begin{array}{c}.225 \\
(.010)\end{array}$ \\
\hline $\begin{array}{l}\text { Mean Log Wage of } \\
\text { Ethnically-Similar } \\
\text { Natives }\end{array}$ & 1.109 & 1.234 & 1.287 & 1.180 & 1.237 & 1.348 & 1.441 & 1.488 & 1.574 & 1.393 & 1.441 & 1.496 \\
\hline $\begin{array}{c}\text { Mean Log Wage of } \\
\text { All Natives }\end{array}$ & 1.350 & 1.408 & 1.462 & 1.350 & 1.408 & 1.462 & 1.350 & 1.408 & 1.462 & 1.350 & 1.408 & 1.462 \\
\hline Sample Size: & & & & & & & & & & & & \\
\hline Immigrants & 3,184 & 25,153 & 55,731 & 3,753 & 17,928 & 34,250 & 2,810 & 22,337 & 46,159 & 20,490 & 50,068 & 45,789 \\
\hline Natives & 2,095 & 4,101 & 5,770 & 2,237 & 2,558 & 3,091 & 619 & 1,042 & 1.420 & 127,235 & 156.368 & 180,953 \\
\hline $\begin{array}{l}\text { Percent of Immigrant } \\
\text { Stock in Ethric Group }\end{array}$ & 9.7 & 18.5 & 26.2 & 11.4 & 13.1 & 16.1 & 8.6 & 16.4 & 21.7 & 62.4 & 36.8 & 21.5 \\
\hline
\end{tabular}

Note: Standard errors are reported in parentheses. 
It is worth stressing that the wage gap between Mexican immigrants and Mexican natives greatly underestimates the "true" economic status of Mexican immigrants in the United States. After all, Mexican natives are themselves a relatively disadvantaged group, earning 17 percent less than the typical U.S. native in 1990 (see the rows in Table 8 reporting the mean log wages of ethnic natives and of all natives).

As with the Mexican population, Table 8 documents that the relative wage of other Hispanic immigrants fell across successive cohorts. The most recent wave of other Hispanics earned 19.1 percent less than ethnically-similar natives in 1970 , but by 1990 the most recent wave earned 38.0 percent less. In fact, the data reveal negative cohort effects even among Asian immigrants, where the newest arrivals earned 21 percent less than Asian natives in 1970, 31.9 percent less in 1980, and 37.5 percent less in 1990 . It is worth pointing out, however, that these wage differentials (unlike the Mexican ones) overstate the wage disadvantage of Asian immigrants. After all, in 1990 Asian natives have 11 percent higher earnings than the average native-born worker in the population. In contrast to these groups, the data indicate that the relative wage of successive waves of European and Canadian immigrants increased between 1970 and 1990. The most recent "white" arrivals earned 6.3 percent less than natives in 1970 , but by 1990 they earned only .8 percent less.

As noted earlier, a better measure of the wage convergence between each of the immigrant groups and ethnically-similar natives is obtained by tracking particular age cohorts across Censuses. Table 9 reports that after controlling for age at migration most ethnic groups experience relatively sluggish wage growth, even in contrast with natives who share the same ethnic background. For example, Mexican immigrants aged 25-34 who arrived in the late 1960 s earned 31 percent less than Mexican natives in 1970 and 22 percent less than Mexican natives in 
TABLE 9. TRACKING AGE COHORTS OF ETHNIC GROUPS ACROSS CENSUSES ((Immigrant Log Wage Relative to Natives of Same Ethnicity, Using Age/Education Delator)

\begin{tabular}{|c|c|c|c|c|c|c|c|c|c|c|c|c|}
\hline \multirow[b]{2}{*}{$\frac{\text { Age Cohort }}{1960-64 \text { Arrivals }}$} & \multicolumn{3}{|c|}{ Mexican } & \multicolumn{3}{|c|}{ Other Hispanic } & \multicolumn{3}{|c|}{ Asian } & \multicolumn{3}{|c|}{ White } \\
\hline & 1970 & 1980 & $\underline{1990}$ & $\underline{1970}$ & 1980 & $\underline{1990}$ & $\underline{1970}$ & $\underline{1980}$ & $\underline{1990}$ & $\underline{1970}$ & $\underline{1980}$ & $\underline{1990}$ \\
\hline $15-24$ in 1970 & - & $\begin{array}{l}. .018 \\
(.026)\end{array}$ & $\begin{array}{l}-.052 \\
(.056)\end{array}$ & - & $\begin{array}{l}.185 \\
(.025)\end{array}$ & $\begin{array}{l}.256 \\
(.047)\end{array}$ & - & $\begin{array}{l}.019 \\
(.040)\end{array}$ & $\begin{array}{l}.002 \\
(.070)\end{array}$ & $一$ & $\begin{array}{l}.027 \\
(.015)\end{array}$ & $\begin{array}{l}.098 \\
(.051)\end{array}$ \\
\hline $25-34$ in 1970 & $\begin{array}{l}-.060 \\
(.037)\end{array}$ & $\begin{array}{l}-.101 \\
(.027)\end{array}$ & $\begin{array}{l}-.174 \\
(.047)\end{array}$ & $\begin{array}{l}.086 \\
(.028)\end{array}$ & $\begin{array}{l}.156 \\
(.029)\end{array}$ & $\begin{array}{l}.175 \\
(.042)\end{array}$ & $\begin{array}{l}.067 \\
(.052)\end{array}$ & $\begin{array}{l}.140 \\
(.049)\end{array}$ & $\begin{array}{l}.111 \\
(.038)\end{array}$ & $\begin{array}{c}.091 \\
(.018)\end{array}$ & $\begin{array}{l}.076 \\
(.013)\end{array}$ & $\begin{array}{l}.098 \\
(.043)\end{array}$ \\
\hline $35-44$ in 1970 & $\begin{array}{l}-.253 \\
(.047)\end{array}$ & $\begin{array}{l}-.220 \\
(.035)\end{array}$ & $\begin{array}{l}-.153 \\
(.081)\end{array}$ & $\begin{array}{l}.077 \\
(.033)\end{array}$ & $\begin{array}{l}.082 \\
(.036)\end{array}$ & $\begin{array}{l}.128 \\
(.048)\end{array}$ & $\begin{array}{l}-.166 \\
(.058)\end{array}$ & $\begin{array}{l}.040 \\
(.055)\end{array}$ & $\begin{array}{l}.158 \\
(.072)\end{array}$ & $\begin{array}{l}.044 \\
(.020)\end{array}$ & $\begin{array}{l}.038 \\
(.015)\end{array}$ & $\begin{array}{l}.134 \\
(.056)\end{array}$ \\
\hline $45-54$ in 1970 & $\begin{array}{l}-.206 \\
(.078)\end{array}$ & $\begin{array}{l}-.317 \\
(.058\end{array}$ & - & $\begin{array}{l}-.036 \\
(.049)\end{array}$ & $\begin{array}{l}. .028 \\
(.050)\end{array}$ & - & $\begin{array}{l}-.127 \\
(.086)\end{array}$ & $\begin{array}{l}-.093 \\
(.077)\end{array}$ & - & $\begin{array}{l}-.033 \\
(.028)\end{array}$ & $\begin{array}{c}.007 \\
(.022)\end{array}$ & - \\
\hline 1965-69 Arrivals & & & & & & & & & & & & \\
\hline 15.24 in 1970 & - & $\begin{array}{l}-.124 \\
(.019)\end{array}$ & $\begin{array}{l}-.139 \\
(.031)\end{array}$ & - & $\begin{array}{c}.006 \\
(.024)\end{array}$ & $\begin{array}{c}031 \\
(.046)\end{array}$ & - & $\begin{array}{l}.086 \\
(.034)\end{array}$ & $\begin{array}{c}.03 n \\
(.036)\end{array}$ & - & $\begin{array}{c}.005 \\
(.014)\end{array}$ & $\begin{array}{l}.059 \\
(049)\end{array}$ \\
\hline $25-34$ in 1970 & $\begin{array}{l}-.308 \\
(.037)\end{array}$ & $\begin{array}{l}-.180 \\
(.026)\end{array}$ & $\begin{array}{l}-.217 \\
(.042)\end{array}$ & $\begin{array}{l}. .172 \\
(.030)\end{array}$ & $\begin{array}{l}-.035 \\
(.028)\end{array}$ & $\begin{array}{l}.001 \\
(.042)\end{array}$ & $\begin{array}{l}-.194 \\
(.050)\end{array}$ & $\begin{array}{l}.087 \\
(.043)\end{array}$ & $\begin{array}{c}.082 \\
(.027)\end{array}$ & $\begin{array}{l}.003 \\
(.015)\end{array}$ & $\begin{array}{l}.029 \\
(.012)\end{array}$ & $\begin{array}{l}116 \\
(041)\end{array}$ \\
\hline $35-44$ in 1970 & $\begin{array}{l}-.393 \\
(.058)\end{array}$ & $\begin{array}{l}-.262 \\
(.041)\end{array}$ & $\begin{array}{l}-.345 \\
(.110)\end{array}$ & $\begin{array}{c}-.173 \\
(.035)\end{array}$ & $\begin{array}{l}-.103 \\
(.033)\end{array}$ & $\begin{array}{l}-.067 \\
(.044)\end{array}$ & $\begin{array}{l}-.165 \\
(.058)\end{array}$ & $\begin{array}{l}-.140 \\
(.055)\end{array}$ & $\begin{array}{l}-.058 \\
(.061)\end{array}$ & $\begin{array}{l}-.055 \\
(.021)\end{array}$ & $\begin{array}{l}-.064 \\
(.016)\end{array}$ & $\begin{array}{l}.090 \\
(.059)\end{array}$ \\
\hline $45-54$ in 1970 & $\begin{array}{l}-.344 \\
(.077)\end{array}$ & $\begin{array}{l}-.280 \\
(.070)\end{array}$ & - & $\begin{array}{l}-.246 \\
(.046)\end{array}$ & $\begin{array}{l}-.212 \\
(.049)\end{array}$ & - & $\begin{array}{l}-.373 \\
(.070)\end{array}$ & $\begin{array}{l}-.331 \\
(.062)\end{array}$ & - & $\begin{array}{l}-.116 \\
(.030)\end{array}$ & $\begin{array}{l}-.143 \\
(.024)\end{array}$ & - \\
\hline 1970-74 Arrivals & & & & & & & & & & & & \\
\hline $25-34$ in 1980 & - & $\begin{array}{l}-.217 \\
(.016)\end{array}$ & $\begin{array}{l}-.238 \\
(.018)\end{array}$ & 一 & $\begin{array}{l}-.074 \\
(.021)\end{array}$ & $\begin{array}{l}-.010 \\
(.036)\end{array}$ & - & $\begin{array}{c}.027 \\
(.032)\end{array}$ & $\begin{array}{c}.052 \\
(.022)\end{array}$ & - & $\begin{array}{l}.029 \\
(.012)\end{array}$ & $\begin{array}{c}.078 \\
(.044)\end{array}$ \\
\hline $35-44$ in 1980 & - & $\begin{array}{c}-.272 \\
(.025)\end{array}$ & $\begin{array}{c}. .347 \\
(.035)\end{array}$ & - & $\begin{array}{l}-.124 \\
(.030)\end{array}$ & $\begin{array}{l}-.070 \\
(.045)\end{array}$ & - & $\begin{array}{l}-.104 \\
(.043)\end{array}$ & $\begin{array}{l}.040 \\
(.027)\end{array}$ & - & $\begin{array}{l}.07 ! \\
(.016)\end{array}$ & $\begin{array}{c}.030 \\
(.053)\end{array}$ \\
\hline $45-54$ in 1980 & - & $\begin{array}{l}-.382 \\
(.038)\end{array}$ & $\begin{array}{l}-.377 \\
(.091)\end{array}$ & - & $\begin{array}{l}-.189 \\
(.038)\end{array}$ & $\begin{array}{l}-.151 \\
(.063)\end{array}$ & - & $\begin{array}{c}. .255 \\
(.053)\end{array}$ & $\begin{array}{l}-.116 \\
(.055)\end{array}$ & - & $\begin{array}{l}-.222 \\
(.021)\end{array}$ & $\begin{array}{l}.052 \\
(.084)\end{array}$ \\
\hline 1975-79 Arrivals & & & & & & & & & & & & \\
\hline $25-34$ in 1980 & - & $\begin{array}{c}. .413 \\
(.017)\end{array}$ & $\begin{array}{l}-.350 \\
(.022)\end{array}$ & - & $\begin{array}{l}-.242 \\
(.025)\end{array}$ & $\begin{array}{l}-.183 \\
(.035)\end{array}$ & - & $\begin{array}{l}-.220 \\
(.032)\end{array}$ & $\begin{array}{l}-.108 \\
(.017)\end{array}$ & - & $\begin{array}{c}-.006 \\
(.011)\end{array}$ & $\begin{array}{c}.111 \\
(.042)\end{array}$ \\
\hline $35-44$ In 1980 & 一 & $\begin{array}{c}-.483 \\
(.027)\end{array}$ & $\begin{array}{l}-.457 \\
(.044)\end{array}$ & - & $\begin{array}{l}-.254 \\
(.037)\end{array}$ & $\begin{array}{l}-.165 \\
(.066)\end{array}$ & - & $\begin{array}{l}-.330 \\
(.049)\end{array}$ & $\begin{array}{l}-.299 \\
(.027)\end{array}$ & - & $\begin{array}{c}-.018 \\
(.051)\end{array}$ & $\begin{array}{c}.041 \\
(.060)\end{array}$ \\
\hline 45.54 in 1980 & - & $\begin{array}{l}-.513 \\
(.039)\end{array}$ & $\begin{array}{l}-.497 \\
(.105)\end{array}$ & - & $\begin{array}{l}-.269 \\
(.053)\end{array}$ & $\begin{array}{l}-.128 \\
(.117)\end{array}$ & - & $\begin{array}{l}. .533 \\
(.054)\end{array}$ & $\begin{array}{l}-.414 \\
(.043)\end{array}$ & - & $\begin{array}{c}-.064 \\
(.022)\end{array}$ & $\begin{array}{l}.031 \\
(.099)\end{array}$ \\
\hline 1980-84 Arrivals & & & & & & & & & & & & \\
\hline $25-34$ in 1990 & - & - & $\begin{array}{c}-.288 \\
(.013)\end{array}$ & - & - & $\begin{array}{l}-.220 \\
(.016)\end{array}$ & - & - & $\begin{array}{l}-.161 \\
(.014)\end{array}$ & - & - & $\begin{array}{c}117 \\
(.038)\end{array}$ \\
\hline $35-44$ in 1990 & - & - & $\begin{array}{c}-.504 \\
(.031)\end{array}$ & - & - & $\begin{array}{l}-.319 \\
(.024)\end{array}$ & - & - & $\begin{array}{l}-340 \\
(.017)\end{array}$ & - & - & $\begin{array}{l}.096 \\
(.042)\end{array}$ \\
\hline $45-54$ in 1990 & - & - & $\begin{array}{l}-.562 \\
(.056)\end{array}$ & - & 一 & $\begin{array}{l}-.318 \\
(.041)\end{array}$ & - & - & $\begin{array}{l}-.528 \\
(.027)\end{array}$ & - & - & $\begin{array}{c}.034 \\
(.063)\end{array}$ \\
\hline 1985-89 Arrivals & & & & & & & & & & & & \\
\hline $25-34$ in 1990 & - & - & $\begin{array}{l}-.414 \\
(.015)\end{array}$ & - & - & $\begin{array}{l}-.331 \\
(.018)\end{array}$ & - & - & $\begin{array}{l}-279 \\
(015)\end{array}$ & - & - & $\begin{array}{c}.039 \\
(.028)\end{array}$ \\
\hline $35-44$ in 1990 & - & - & $\begin{array}{l}-.599 \\
(.035)\end{array}$ & - & - & $\begin{array}{l}-.450 \\
(.031)\end{array}$ & - & - & $\begin{array}{l}.365 \\
(.021)\end{array}$ & - & - & $\begin{array}{l}-012 \\
(.039)\end{array}$ \\
\hline 45.54 in 1990 & - & - & $\begin{array}{l}-.655 \\
(.056)\end{array}$ & - & - & $\begin{array}{l}-.465 \\
(.061)\end{array}$ & - & - & $\begin{array}{l}-.561 \\
(.032)\end{array}$ & - & - & $\begin{array}{c}.014 \\
(.063)\end{array}$ \\
\hline
\end{tabular}

Note: Standard errors are reported in parentheses. 
1990 , so that the wage gap narrows by only 9 percent over a 20 -year period. Similarly, the relative wage of white immigrants aged $25-34$ who migrated in the late 1960 s increased from only +.3 percent to +12 percent between 1970 and 1990 . Finally, the data indicate that even Asian immigrants who arrived after 1970 have relatively slow wage growth. The relative wage of Asian immigrants aged 25-34 who arrived in the late 1970s increased by only 11 percent during their first 10 years in the United States.

To describe the trend in relative wages over the life cycle for these immigrant groups I reestimate the basic regression models presented in the previous section for each of the ethnic groups. Two sets of models are estimated: the first ignores the impact of age-at-migration, and the second includes age-at-migration as a variable (and restricts the age coefficients to be the same for immigrants and ethnically-similar natives). The estimated regression coefficients are presented in the Appendix.

Table 10 reports the entry wage gap between immigrants and ethnically-similar natives implied by the regressions which omit a person's age-at-migration, while Figures 3 through 6 use the regression coefficients to trace out the predicted age-earnings profiles of immigrants relative to those of ethnic natives. ${ }^{19}$ The entry wage differentials reported in Table 9 reconfirm the insights provided by the descriptive statistics discussed earlier. For example, at the time of entry, recent Mexican immigrant natives earn substantially less than Mexican natives. Among the immigrants who entered in the late 1980 s, the wage gap is -27.7 percent, while among those who arrived in the late 1960 s it was only -11.9 percent. It is evident that much of this wage gap arises because Mexican immigrants have much less schooling than Mexican natives. Controlling for

\footnotetext{
19 As is evident from the cohort effects illustrated in the figures, the entry wage differentials implied by the regressions which include age-at-migration are similar to those reported in Table 10.
} 
TABLE 10. PREDICTED WAGE OF IMMIGRANT ETHNIC GROUPS AT TIME OF ENTRY, RELATIVE TO NATIVES OF SAME ETHNICITY

(Assuming Immigrants Enter U.S. at Age 20)

Log Wage Rate:

1985-1989 Arrivals

1980-1984 Arrivals

1975-1979 Arrivals

1970-1974 Arrivals

1965-1969 Arrivals

1960-1964 Arrivals

1950-1959 Arrivals
Mexican

$-.2767$

$(.0450)$

$-.2581$

$(.0458)$

$-.2152$

(.0470)

$-.1493$

(.0493)

$-.1194$

(.0522)

$-.0854$

$(.0557)$

$-.0495$

(.0610)
Other Hispanic

$-.2542$

(.0591)

$-.2433$

$(.0603)$

$-.1644$

$(.0621)$

$-.1120$

(.0655)

$-.1160$

(.0699)

.0103

$(.0757)$

$-.0432$

(.0849)
Asian

$-.2809$

(.0954)

$-.2591$

(.0961)

$-.1060$

(.0972)

.0715

(.0996)

.1585

(.1027)

.2583

(.1069)

.2516

(.1133)
White

$-.0457$

(.0173)

$-.0419$

(.0190)

$-.0509$

(.0178)

$-.1398$

(.0191)

$-.0940$

$(.0188)$

$-.0722$

$(.0201)$

$-.0644$

(.0213)

Log Wage Rate,

Controlling for Education

1985-1989 Arrivals

1980-1984 Arrivals

1975-1979 Arrivals

1970-1974 Arrivals

1965-1969 Arrivals

1960-1964 Arrivals

1950-1959 Arrivals

$\begin{array}{cc}-.1123 & -.1876 \\ (.0446) & (.0577) \\ -.0742 & -.1807 \\ (.0455) & (.0594) \\ -.0170 & -.1314 \\ (.0469) & (.0618) \\ .0463 & -.0931 \\ (.0495) & (.0658) \\ .0685 & -.1207 \\ (.0527) & (.0710) \\ .0959 & -.0606 \\ (.0564) & (.0773) \\ .1182 & -.1189 \\ (.0622) & (.0874)\end{array}$

$\begin{array}{cc}-.1973 & -.1368 \\ (.0914) & (.0165) \\ -.1592 & -.1341 \\ (.0924) & (.0184) \\ -.0551 & -.1437 \\ (.0940) & (.0178) \\ .0330 & -.1738 \\ (.0968) & (.0193) \\ .0773 & -.1590 \\ (.1002) & (.0193) \\ .1266 & -.1672 \\ (.1047) & (.0207) \\ .1323 & -.1838 \\ (.1113) & (.0223)\end{array}$

Notes: Standard errors are reported in parentheses. The predicted wage differentials at the time of entr. are based on the regression coefficients reported in Table A-1. In the bottom panel, the simulation uses the mean educational attainment in the ethnic group to predict the relative wage and "tums on" the dummy: variable indicating if the worker lives in a metropolitan area. The mean educational attainment for Mexicans is 7.611 years; for other Hispanics 11.201 years; for Asians 14.066 years; and for whites 13.026 years. 
differences in educational attainment between the two groups reduces the wage gap for the most recent immigrant cohort by more than half.

The predicted age-earnings profiles suggest that the wage growth experienced by some of the ethnic groups, particularly white immigrants, allows them to "catch up" with ethnically-similar natives. The relative wage growth experienced by Mexicans and Asians, however, does not permit them to reach wage parity with their ethnic counterparts.

The comparison of particular subsets of the immigrant population to ethnically-similar natives has gained some popularity in the literature (see, for example, Borjas, 1985; LaLonde and Topel, 1992; Smith, 1992). These studies are partly motivated by an important question: will the "new immigration" exacerbate the ethnic differences now prevalent in the U.S. labor market? For example, the fact that the relative wage of current Mexican immigrants does not converge with that of the relatively disadvantaged group of Mexican natives suggests that the Hispanic/nonHispanic wage gap may increase substantially in the future.

There are, however, a number of measurement and conceptual problems which cloud the interpretation of many of the intra-ethnic comparisons presented in this section (as well as of those that dominate the literature). Most obvious is the aggregation bias introduced by pooling immigrants from different countries into a particular "ethnicity" (such as aggregating Cubans, Salvadorans, and Chileans into other Hispanics; or Indians, Japanese, and Laotians into Asians). Because immigrant groups from different countries differ substantially, it is doubtful that the composite "other Hispanic" or the composite "Asian" resembles the average individual in any of the national origin groups making up the ethnic category. Moreover, there are significant changes in the national origin mix of the immigrant flow over very short time periods. For example, Chinese immigrants made up only 8.1 percent of the Asian immigrant flow in the 1960s, but made 
Figure 3. Predicted Wage Profiles of Mexican Immigrants,

Relative to Mexican Natives

(Using Age/Education Deflator)

Immigrant Wage Profile

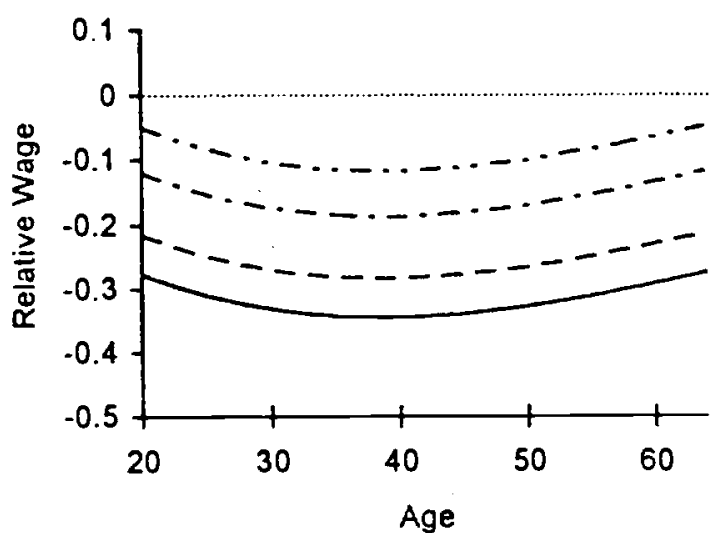

Adjusted for Age-At-Migration

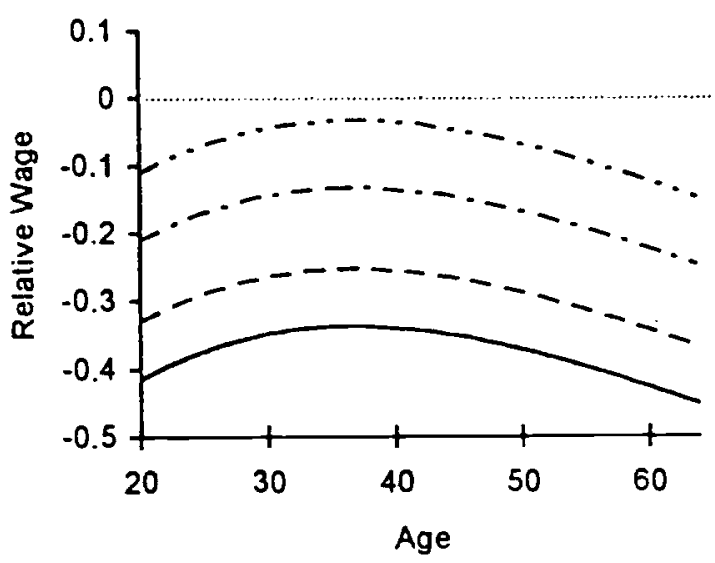

Adjusted for Education

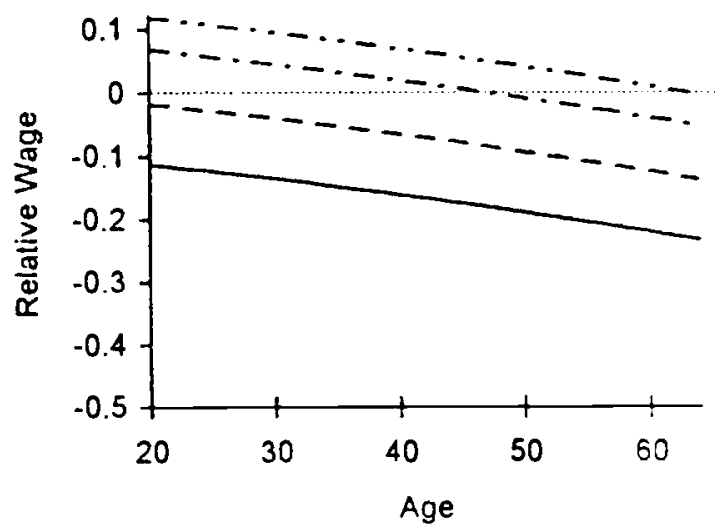

Adjusted for Education and Age-At-Migration

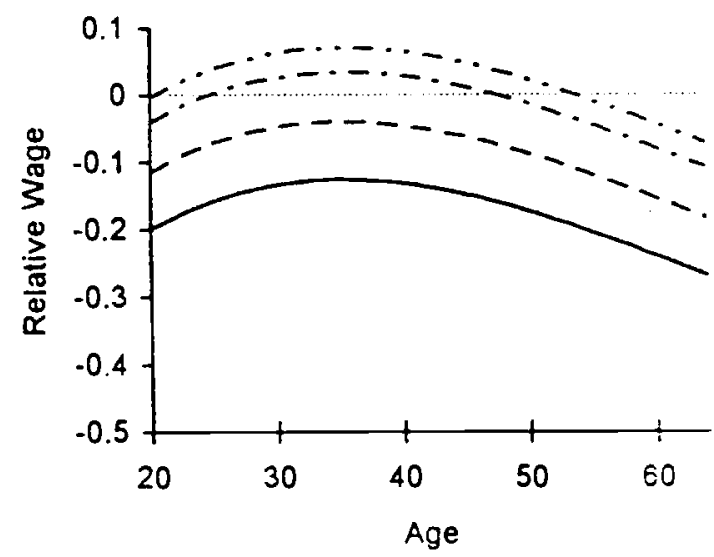

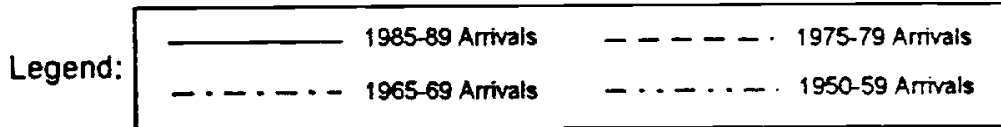


Figure 4. Predicted Wage Profiles of Other Hispanic Immigrants,

Relative to Other Hispanic Natives

(Using Age/Education Deflator)

immigrant Wage Profile

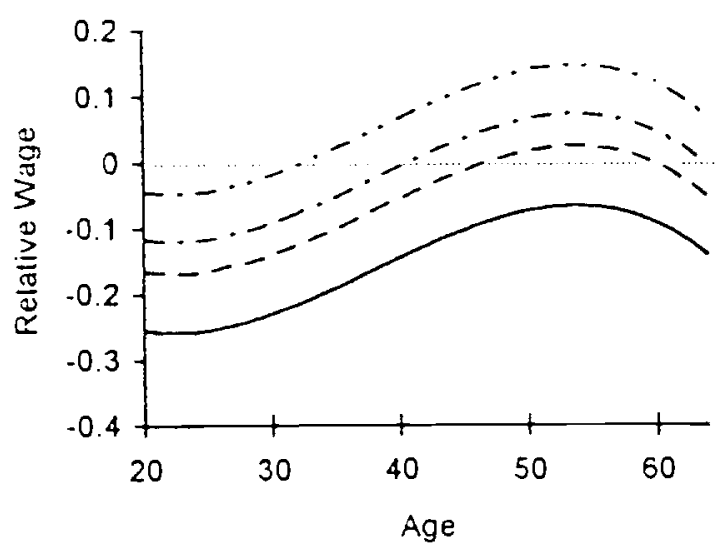

Adjusted for Age-At-Migration

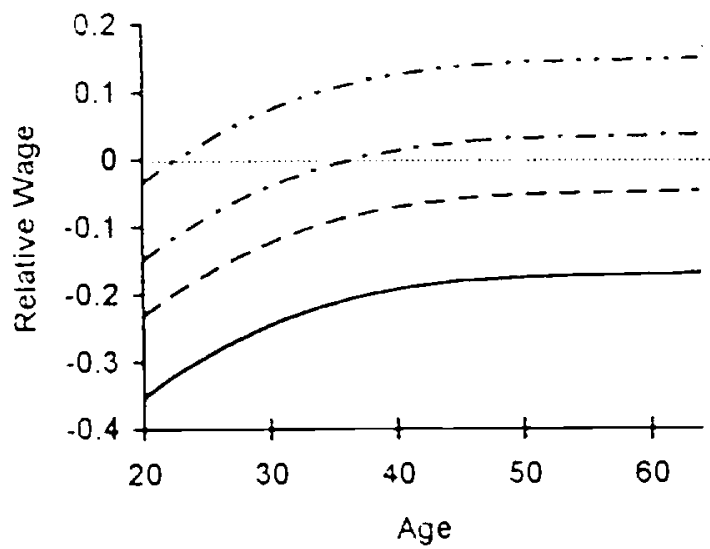

Adjusted for Education

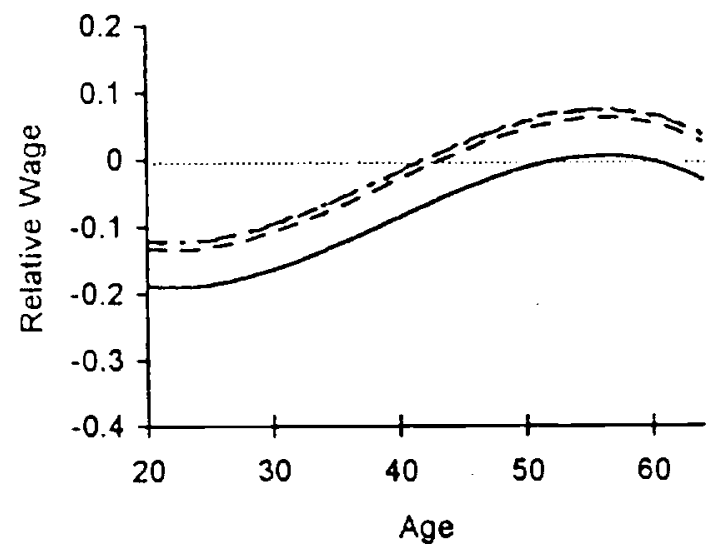

Adjusted for Education and Age-At-Migration

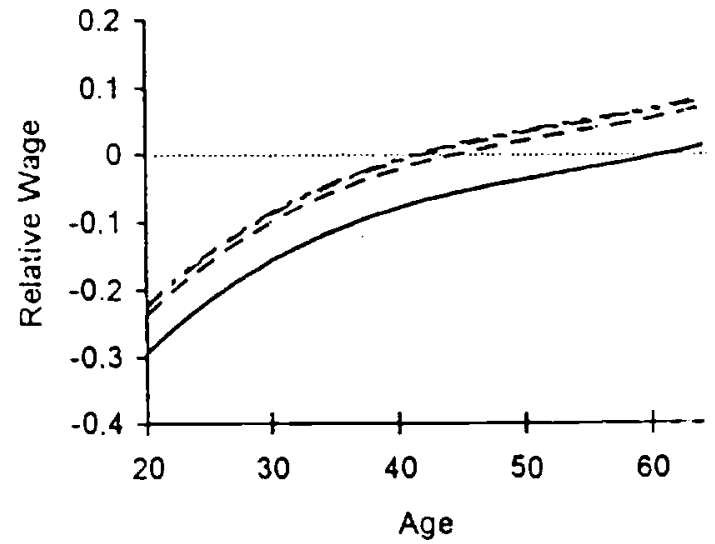

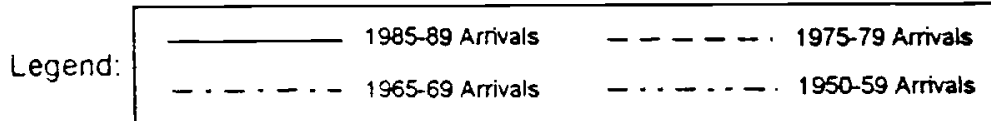


Figure 5. Predicled Wage Profiles of Asian Immigrants,

Relative to Asian Natives

(Using Age/Education Deflator)

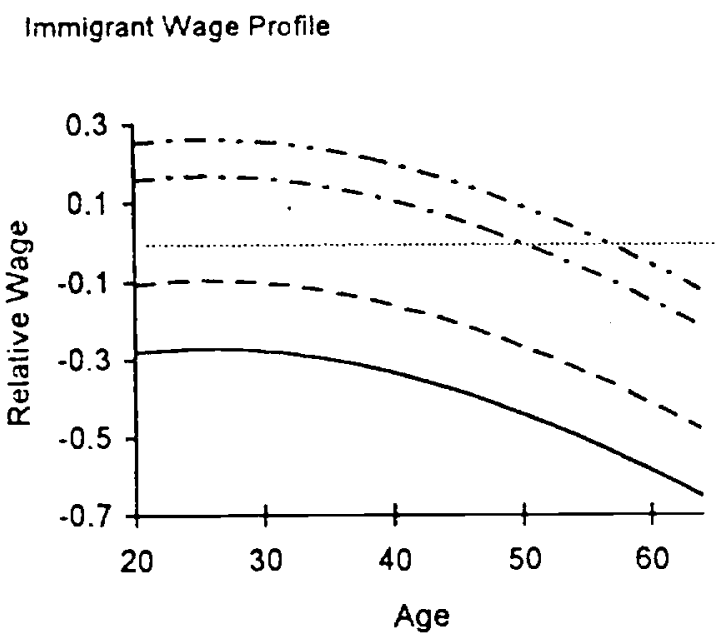

Adjusted for Age-At-Migration

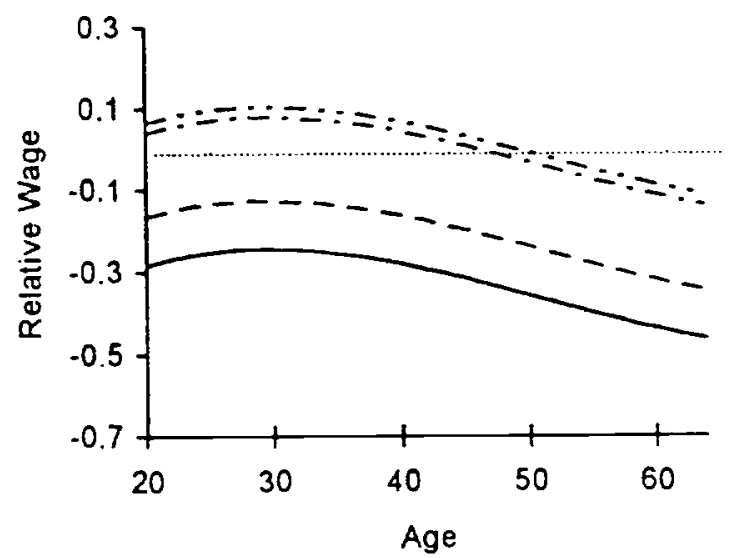

Adjusted for Education

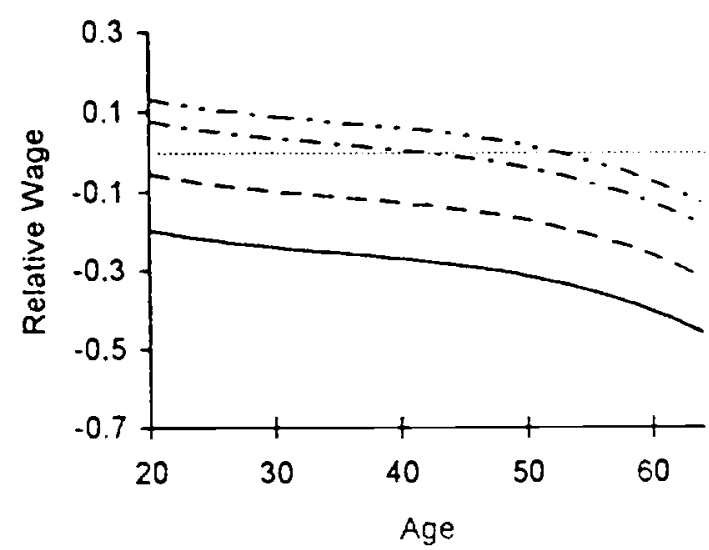

Adjusted for Education and Age-At-Migration

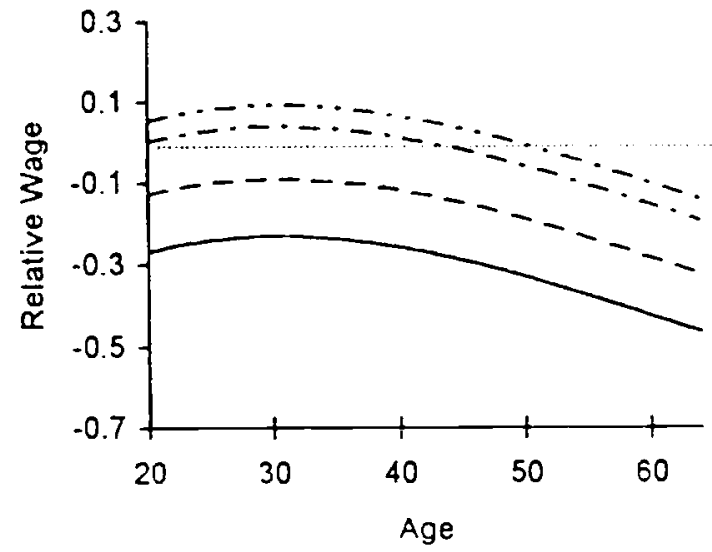

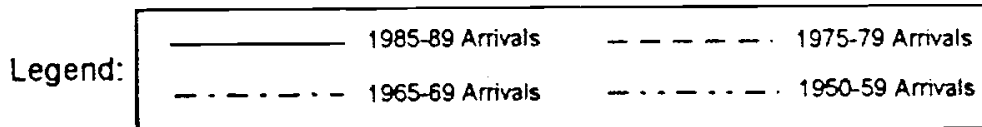


Figure 6. Predicted Wage Profiles of White Immigrants,

Relative to White Natives

(Using Age/Education Deflator)

Immigrant Wage Profile

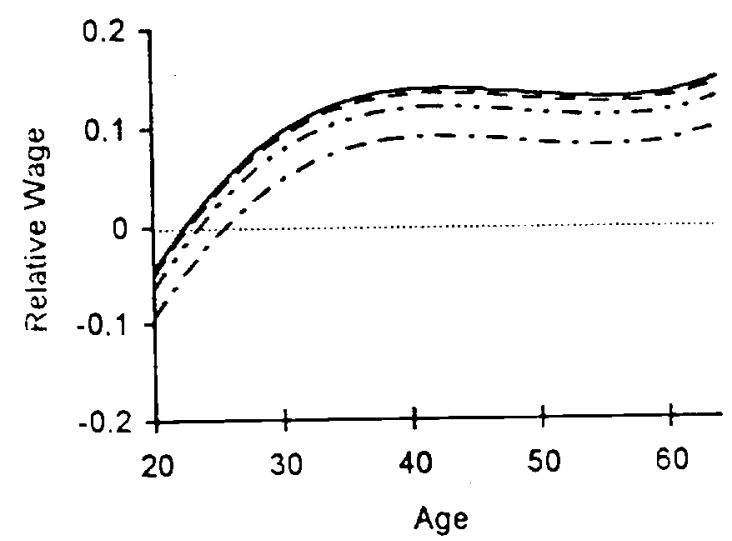

Adjusted for Age-At-Migration

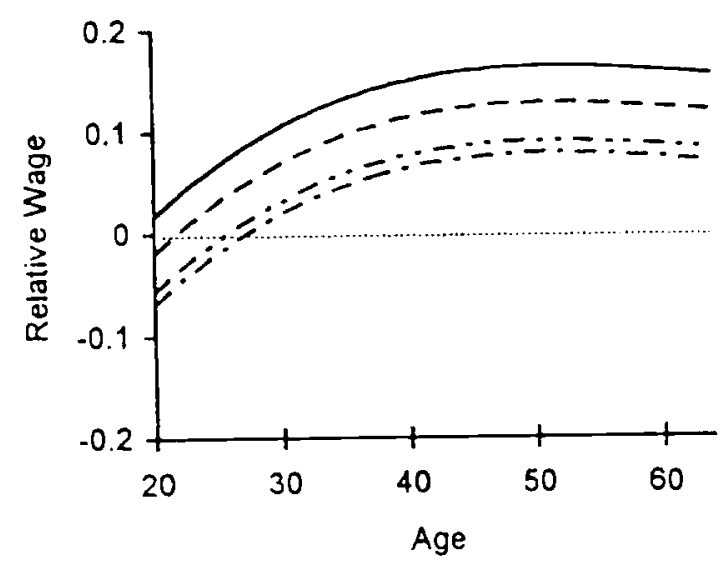

Adjusted for Education

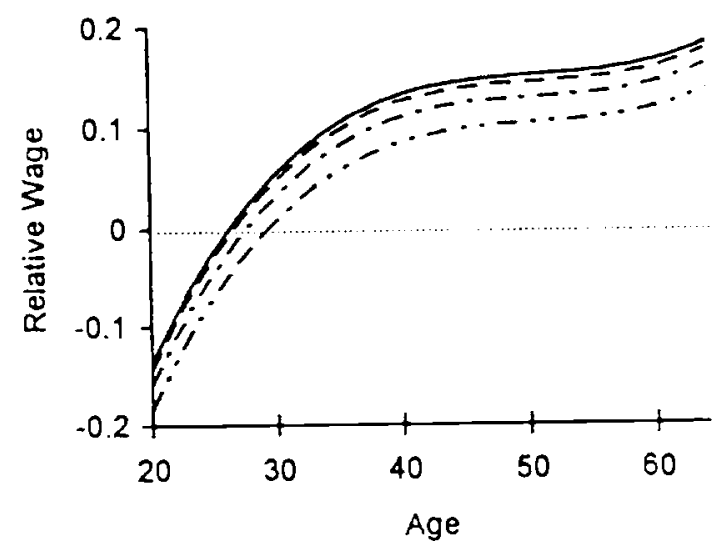

Adjusted for Education and Age-At-Migration

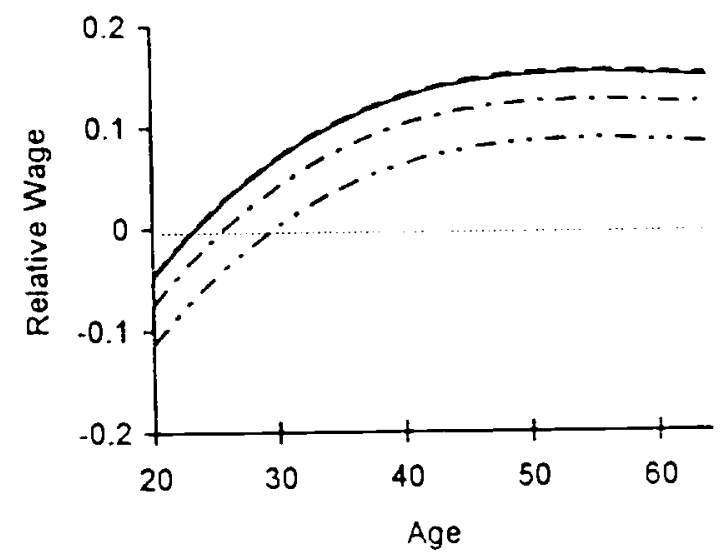

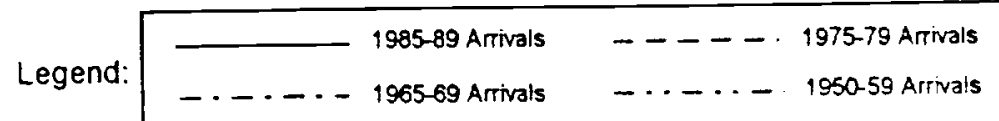


up 12.7 percent during the 1980s. As a result, the observed cohort effects among Asians or other Hispanics cannot be easily interpreted unless the analysis also specifies how the national origin mix of the population is changing within any given ethnic group. ${ }^{20}$

In fact, not only is the national origin composition of the immigrant sample in a particular ethnic category changing substantially over time, but the composition of the native-born sample is changing as well. In 1970, for example, there were very few adult Cubans in the "other Hispanic" native sample. By 1990 , as the U.S.-born children of the early Cuban refugee waves enter the labor market, the wage of the other Hispanic native base is partly determined by the skill endowment of immigrant flows that arrived a generation earlier. The comparison of other Hispanic immigrants to other Hispanic natives in 1970 thus differs fundamentally from the comparison of other Hispanic immigrants to other Hispanic natives in 1990. Similarly, the ancestry of the native-born Asian population has changed rapidly in the past three decades, and will surely change even more drastically in the future. In effect, the trend in the wage of immigrants relative to ethnically-similar natives cannot be understood unless the analysis also addresses how earlier immigrant flows are systematically changing the ethnic background of the native base.

Finally, these intra-ethnic comparisons can be very misleading. What would we conclude, for example, if the data had revealed that the relative wage of Mexican immigrants converged to that of Mexican natives, or that the relative wage of Asian immigrants converged to that of Asian

\footnotetext{
20 The fact that the national origin mix of particular ethnic groups changes drastically over time suggests that a useful generalization of the analysis reported in this paper would allow for cohor differences not only in entry wages but also in the rate of wage convergence. Such a study might provide a better explanation of the wage determination process for ethnic groups where the sample composition changed significantly in the past three decades, such as Asians.
} 
natives? The fact remains that the wage of Mexican natives is itself 17 percent below that of the typical U.S.-bom worker, while the wage of Asian natives is 11 percent above. Intra-Mexican or intra-Asian convergence, therefore, is a less interesting phenomenon if we are concerned about the impact of immigration policy on the costs of welfare programs or on the contribution of immigrants to the economy's skill endowment.

\section{Summary}

This paper uses the 1970,1980, and 1990 Public Use Samples of the U.S. Census to document how the contribution of immigrants to the skill endowment of the labor force changed during the 1980s. The study contains a number of potentially important empirical results.

1. The relative decline in wages across successive immigrant waves continued into the 1980s. Even after adjusting for changes in the wage structure between 1970 and 1990, the entry wage of immigrant cohorts declined by about 9 percentage points in the 1970 s, and by an additional 6 percentage points in the 1980s.

2. There is little evidence to suggest that immigrants reach wage parity with the typical U.S.-born worker during their working lives. Although the relative wage of the typical immigrant entering the United States grows by about 10 percentage points during the first two decades in the country, this rate of wage convergence is much too small to compensate for the low entry wage of recent immigrant waves. As a result, it is likely that the relative wages of post-1970 immigrants will remain about 15 to 20 percentage points below those of natives throughout much of their working lives.

3. It is unlikely that recent Mexican and Asian immigrants will reach wage parity with their ethnically-similar native counterparts. 
The economic impact of immigration is now being extensively debated in the United States. The data presented in this paper suggest a somewhat pessimistic assessment of the contribution that recent immigrants make to the skill endowment of the U.S. labor force. It is likely that the significant changes in immigrant skills and the sluggish wage growth experienced by immigrants relative to natives greatly influenced many aspects of the U.S. economy during the 1980s, including the employment and earnings opportunities of natives, and the social and fiscal costs associated with immigration. As a result, the debate over the economic impact of the "new immigration" is sure to continue. 


\section{REFERENCES}

Baker, Michael, and Benjamin, Dwayne. "The Performance of Immigrants in the Canadian Labor Market," Joumal of Labor Economics 12 (July 1994): 369-405.

Borjas, George J. "Assimilation, Changes in Cohor Quality, and the Earnings of Immigrants," Journal of Labor Economics 3 (October 1985): 463-489.

Borjas, George J. "Self-Selection and the Earnings of Immigrants," American Economic Review 77 (September 1987): 531-553.

Borjas, George J. "National Origin and the Skills of Immigrants in the Postwar Period." In Immigration and the Work Force: Economic Consequences for the United States and Source Areas, edited by George J. Borjas and Richard B. Freeman; pp. 17-47. Chicago: University of Chicago Press, 1992.

Borjas, George J., and Bratsberg, Bernt. "Who Leaves? The Outmigration of the Foreign-Born." Unpublished Manuscript. San Diego: University of Califomia, San Diego, August 1994

Card, David. "The Impact of the Mariel Boatlift on the Miami Labor Market," Industrial and Labor Relations Review 43 (January 1990): 245-257.

Carliner, Geoffrey. "Wages, Earnings, and Hours of First, Second and Third Generation American Males," Economic Inquiry 18 (January 1980): 87-102.

Chiswick, Barry R. "The Effect of Americanization on the Earnings of Foreign-Born Men," Journal of Political Economy 86 (October 1978): 897-921.

Chiswick, Barry R. "Is the New Immigration Less Skilled than the Old?" Journal of Labor Economics 4 (April 1986): 168-192.

Duleep, Harriet Orcutt, and Regets, Mark C. "The Elusive Concept of Immigrant Quality." Unpublished Manuscript. Washington, D.C.: The Urban Institute, 1992.

Friedberg, Rachel. "The Labor Market Assimilation of Immigrants in the United States: The Role of Age at Arrival." Unpublished Manuscript. Providence, RI: Brown University, 1992.

Funkhouser, Edward, and Trejo, Stephen J. "The Labor Market Skills of Recent Male Immigrants: Evidence from the Current Population Surveys," Industrial and Labor Relations Review, in press, 1995.

Juhn, Chinhui, Murphy, Kevin M., and Pierce, Brooks. "Wage Inequality and the Rise in Retums to Skills," Journal of Political Economy 101 (June 1993): 410-442. 
Katz, Lawrence F., and Murphy, Kevin M. "Changes in the Wage Structure, 1963-87: Supply and Demand Factors," Quarterly Journal of Economics 107 (February 1992): 35-78.

Kee, Petr, and van Ophem, Hans. "The Relative Labor Market Position of Immigrants in the Netherlands." Unpublished Manuscript. Amsterdam: University of Amsterdam, 1992.

LaLonde, Robert J., and Topel, Robert H.. "The Assimilation of Immigrants in the U.S. Labor Market." In Immigration and the Work Force: Economic Consequences for the United States and Source Areas, edited by George J. Borjas and Richard B. Freeman; pp. 67-92. Chicago: University of Chicago Press, 1992.

Murphy, Kevin M., and Welch, Finis. "The Structure of Wages," Quarterly Journal of Economics 107 (February 1992): 215-326.

Pischke, Jörn-Steffen. "Assimilation and the Earnings of Guestworkers in Germany." Unpublished Manuscript. Cambridge: Massachusetts Institute of Technology, 1993.

Ramos, Fernando. "Out-Migration and Return Migration of Puerto Ricans." In Immigration and the Work Force: Economic Consequences for the United States and Source Areas, edited by George J. Borjas and Richard B. Freeman; pp. 49-66. Chicago: University of Chicago Press, 1992.

Smith, James. "Hispanics and the American Dream: An Analysis of Hispanic Male Labor Market Wages, 1940-1980." Unpublished Manuscript. Santa Monica, CA: The Rand Corporation, 1992.

U.S. Immigration and Naturalization Service. Statistical Yearbook of the Immigration and Naturalization Service. 1992. Washington, D.C.: U.S. Government Printing Office, 1993.

Yuengert, Andrew. "Immigrant Earnings, Relative to What? The Importance of Earnings Function Specification and Comparison Points," Journal of Applied Econometrics 9 (JanuaryMarch 1994): 71-90. 
TABLE A-1. REGRESSION USING POOLED 1970, 1980, AND 1990 CENSUSES FOR ETHNIC GROUPS (Dependent Variable $=$ Log Wage Rate, Using Age/Education Deflator)

\begin{tabular}{|c|c|c|c|c|c|c|c|c|}
\hline \multirow{3}{*}{$\frac{\text { Variable }}{\text { Intercept }}$} & \multicolumn{2}{|c|}{ Mexican } & \multicolumn{2}{|c|}{ Other Hispanic } & \multicolumn{2}{|c|}{ Asian } & \multicolumn{2}{|c|}{ White } \\
\hline & (1) & (2) & (1) & (2) & (1) & $(2)$ & (1) & $(2)$ \\
\hline & -.849 & -1.357 & -1.372 & -1.818 & -1.740 & -2.195 & -.690 & -1.303 \\
\hline & $(.373)$ & $(.365)$ & $(.484)$ & $(.468)$ & $(.792)$ & $(.749)$ & $(.058)$ & $(.055)$ \\
\hline Age & $\begin{array}{l}.136 \\
(.028)\end{array}$ & $\begin{array}{l}.118 \\
(.028)\end{array}$ & $\begin{array}{l}.190 \\
(.036)\end{array}$ & $\begin{array}{l}.171 \\
(.035)\end{array}$ & $\begin{array}{l}.212 \\
(.059)\end{array}$ & $\begin{array}{l}.198 \\
(.056)\end{array}$ & $\begin{array}{l}.123 \\
(.004)\end{array}$ & $\begin{array}{l}.100 \\
(.004)\end{array}$ \\
\hline $\mathrm{Age}^{2}$ & $\begin{array}{l}-.003 \\
(.001)\end{array}$ & $\begin{array}{l}-.002 \\
(.001)\end{array}$ & $\begin{array}{l}-.004 \\
(.001)\end{array}$ & $\begin{array}{l}-.004 \\
(.001)\end{array}$ & $\begin{array}{l}-.004 \\
(.001)\end{array}$ & $\begin{array}{l}.004 \\
(.001)\end{array}$ & $\begin{array}{l}-.002 \\
(.000)\end{array}$ & $\begin{array}{l}-.002 \\
(.000)\end{array}$ \\
\hline Age $^{3} \times 10^{-4}$ & $\begin{array}{l}.153 \\
(.054)\end{array}$ & $\begin{array}{l}.135 \\
(.052)\end{array}$ & $\begin{array}{l}.296 \\
(.068)\end{array}$ & $\begin{array}{l}.253 \\
(.066)\end{array}$ & $\begin{array}{l}.260 \\
(.108)\end{array}$ & $\begin{array}{l}.245 \\
(.102)\end{array}$ & $\begin{array}{l}.107 \\
(.008)\end{array}$ & $\begin{array}{l}.079 \\
(.007)\end{array}$ \\
\hline Immigrant $(=1)$ & $\begin{array}{l}.572 \\
(.397)\end{array}$ & $\begin{array}{l}.768 \\
(.388)\end{array}$ & $\begin{array}{l}.754 \\
(.511)\end{array}$ & $\begin{array}{l}1.095 \\
(.495)\end{array}$ & $\begin{array}{l}.102 \\
(.810)\end{array}$ & $\begin{array}{l}.435 \\
(.765)\end{array}$ & $\begin{array}{l}-.466 \\
(.123)\end{array}$ & $\begin{array}{l}-.247 \\
(.117)\end{array}$ \\
\hline Age $\times$ Immigrant & $\begin{array}{l}-.057 \\
(.030)\end{array}$ & $\begin{array}{l}-.045 \\
(.029)\end{array}$ & $\begin{array}{l}-.082 \\
(.038)\end{array}$ & $\begin{array}{l}-.084 \\
(.037)\end{array}$ & $\begin{array}{l}-.029 \\
(.060)\end{array}$ & $\begin{array}{l}.058 \\
(.057)\end{array}$ & $\begin{array}{l}.036 \\
(.009)\end{array}$ & $\begin{array}{l}.034 \\
(.008)\end{array}$ \\
\hline $\mathrm{Age}^{2} \times$ Immigrant & $\begin{array}{l}.001 \\
(.001)\end{array}$ & $\begin{array}{l}.001 \\
(.001)\end{array}$ & $\begin{array}{l}.002 \\
(.001)\end{array}$ & $\begin{array}{l}.002 \\
(.001)\end{array}$ & $\begin{array}{l}.001 \\
(.001)\end{array}$ & $\begin{array}{l}.001 \\
(.001)\end{array}$ & $\begin{array}{l}-.001 \\
(.000)\end{array}$ & $\begin{array}{l}-.001 \\
(.000)\end{array}$ \\
\hline $\begin{array}{l}\left(\mathrm{Age}^{3} \times\right. \\
\text { Immigrant }) \times 10^{-4}\end{array}$ & $\begin{array}{l}-.039 \\
(.057)\end{array}$ & $\begin{array}{l}-.039 \\
(.056)\end{array}$ & $\begin{array}{l}-.149 \\
(.072)\end{array}$ & $\begin{array}{l}-.142 \\
(.070)\end{array}$ & $\begin{array}{l}-.058 \\
(.111)\end{array}$ & $\begin{array}{l}-.084 \\
(.104)\end{array}$ & $\begin{array}{l}.066 \\
(.016)\end{array}$ & $\begin{array}{l}.057 \\
(.015)\end{array}$ \\
\hline $\begin{array}{l}\text { Years-Since- } \\
\text { Migration }\end{array}$ & $\begin{array}{l}.021 \\
(.002)\end{array}$ & $\begin{array}{l}.021 \\
(.002)\end{array}$ & $\begin{array}{l}.022 \\
(.003)\end{array}$ & $\begin{array}{l}.024 \\
(.002)\end{array}$ & $\begin{array}{l}.015 \\
(.002)\end{array}$ & $\begin{array}{l}.016 \\
(.002)\end{array}$ & $\begin{array}{l}.012 \\
(.001)\end{array}$ & $\begin{array}{l}.016 \\
(.001)\end{array}$ \\
\hline $\begin{array}{l}\text { (Years-Since- } \\
\text { Migration }^{2}\end{array}$ & $\begin{array}{l}-.0003 \\
(.0001)\end{array}$ & $\begin{array}{l}-.0005 \\
(.0001)\end{array}$ & $\begin{array}{l}-.0003 \\
(.0001)\end{array}$ & $\begin{array}{l}-.0004 \\
(.0001)\end{array}$ & $\begin{array}{l}-.001 \\
(.0001)\end{array}$ & $\begin{array}{l}-.0004 \\
(.0001)\end{array}$ & $\begin{array}{l}-.0003 \\
(.0001)\end{array}$ & $\begin{array}{l}-.0004 \\
(.0001)\end{array}$ \\
\hline $\begin{array}{l}\text { (Years-Since- } \\
\text { Migration) })^{3} \times 10^{-4}\end{array}$ & $\begin{array}{l}.020 \\
(.011)\end{array}$ & $\begin{array}{l}.039 \\
(.011)\end{array}$ & $\begin{array}{l}.024 \\
(.017)\end{array}$ & $\begin{array}{l}.041 \\
(.017)\end{array}$ & $\begin{array}{c}.076 \\
(.017)\end{array}$ & $\begin{array}{l}.035 \\
(.016)\end{array}$ & $\begin{array}{c}.023 \\
(.005)\end{array}$ & $\begin{array}{l}.035 \\
(.005)\end{array}$ \\
\hline 1980-1984 Arrivals & $\begin{array}{l}.019 \\
(.011)\end{array}$ & $\begin{array}{l}.038 \\
(.011)\end{array}$ & $\begin{array}{l}.011 \\
(.015)\end{array}$ & $\begin{array}{l}.007 \\
(.015)\end{array}$ & $\begin{array}{l}.022 \\
(.014)\end{array}$ & $\begin{array}{l}.038 \\
(.013)\end{array}$ & $\begin{array}{l}.004 \\
(.012)\end{array}$ & $\begin{array}{l}.003 \\
(.011)\end{array}$ \\
\hline 1975-1979 Arrivals & $\begin{array}{c}.061 \\
(.015)\end{array}$ & $\begin{array}{l}.095 \\
(.016)\end{array}$ & $\begin{array}{l}.090 \\
(.022)\end{array}$ & $\begin{array}{c}.056 \\
(.023)\end{array}$ & $\begin{array}{l}.175 \\
(.021)\end{array}$ & $\begin{array}{c}.142 \\
(.021)\end{array}$ & $\begin{array}{l}-.005 \\
(.010)\end{array}$ & $\begin{array}{l}. .007 \\
(.010)\end{array}$ \\
\hline 1970-1974 Arrivals & $\begin{array}{l}.127 \\
(.022)\end{array}$ & $\begin{array}{l}.159 \\
(.022)\end{array}$ & $\begin{array}{l}.142 \\
(.031)\end{array}$ & $\begin{array}{c}.094 \\
(.032)\end{array}$ & $\begin{array}{l}.352 \\
(.030)\end{array}$ & $\begin{array}{l}.230 \\
(.030)\end{array}$ & $\begin{array}{l}-.094 \\
(.012)\end{array}$ & $\begin{array}{l}-.037 \\
(.012)\end{array}$ \\
\hline 1965-1969 Arrivals & $\begin{array}{c}.157 \\
(.028)\end{array}$ & $\begin{array}{l}.181 \\
(.029)\end{array}$ & $\begin{array}{l}.138 \\
(.040)\end{array}$ & $\begin{array}{l}.067 \\
(.041)\end{array}$ & $\begin{array}{l}.439 \\
(.040)\end{array}$ & $\begin{array}{l}.275 \\
(.039)\end{array}$ & $\begin{array}{l}-.048 \\
(.012)\end{array}$ & $\begin{array}{l}-.022 \\
(.012)\end{array}$ \\
\hline 1960-1964 Arrivals & $\begin{array}{c}.191 \\
(.034)\end{array}$ & $\begin{array}{l}.208 \\
(.036)\end{array}$ & $\begin{array}{c}.265 \\
(.050)\end{array}$ & $\begin{array}{l}.127 \\
(.051)\end{array}$ & $\begin{array}{l}.519 \\
(.050)\end{array}$ & $\begin{array}{l}.324 \\
(.049)\end{array}$ & $\begin{array}{l}-.027 \\
(.014)\end{array}$ & $\begin{array}{l}-.030 \\
(.014)\end{array}$ \\
\hline 1950-1959 Arrivals & $\begin{array}{l}.227 \\
(.043)\end{array}$ & $\begin{array}{l}.230 \\
(.044)\end{array}$ & $\begin{array}{l}.211 \\
(.063)\end{array}$ & $\begin{array}{c}.069 \\
(.065)\end{array}$ & $\begin{array}{l}.533 \\
(.063)\end{array}$ & $\begin{array}{l}.330 \\
(.062)\end{array}$ & $\begin{array}{l}-.019 \\
(.015)\end{array}$ & $\begin{array}{l}-.047 \\
(.016)\end{array}$ \\
\hline Pre-1950 Arrivals & $\begin{array}{c}.147 \\
(.061)\end{array}$ & $\begin{array}{c}.173 \\
(.063)\end{array}$ & $\begin{array}{l}.206 \\
(.093)\end{array}$ & $\begin{array}{c}.017 \\
(.096)\end{array}$ & $\begin{array}{l}.539 \\
(.090)\end{array}$ & $\begin{array}{l}.396 \\
(.088)\end{array}$ & $\begin{array}{c}.034 \\
(.020)\end{array}$ & $\begin{array}{l}-.037 \\
(.021)\end{array}$ \\
\hline 1970 Period Effect & $\begin{array}{l}-.240 \\
(.048)\end{array}$ & $\begin{array}{l}-.291 \\
(.056)\end{array}$ & $\begin{array}{l}-.171 \\
(.051)\end{array}$ & $\begin{array}{l}-.131 \\
(.059)\end{array}$ & $\begin{array}{l}-.347 \\
(.069)\end{array}$ & $\begin{array}{l}-.546 \\
(.086)\end{array}$ & $\begin{array}{c}.055 \\
(.008)\end{array}$ & $\begin{array}{c}.143 \\
(.012)\end{array}$ \\
\hline 1980 Period Effect & $\begin{array}{l}.061 \\
(.022)\end{array}$ & $\begin{array}{l}-.138 \\
(.026)\end{array}$ & $\begin{array}{l}-.074 \\
(.028)\end{array}$ & $\begin{array}{l}-.228 \\
(.034)\end{array}$ & $\begin{array}{l}-.104 \\
(.030)\end{array}$ & $\begin{array}{l}-.257 \\
(.036)\end{array}$ & $\begin{array}{c}.067 \\
(.007)\end{array}$ & $\begin{array}{c}.053 \\
(.011)\end{array}$ \\
\hline Years of Schooling & - & $\begin{array}{l}.049 \\
(.002)\end{array}$ & - & $\begin{array}{l}.044 \\
(.003)\end{array}$ & - & $\begin{array}{l}.039 \\
(.005)\end{array}$ & -- & $\begin{array}{l}.060 \\
(.000)\end{array}$ \\
\hline $\begin{array}{l}\text { Education } \times \\
\text { Immigrant }\end{array}$ & - & $\begin{array}{l}-.027 \\
(.002)\end{array}$ & - & $\begin{array}{l}. .012 \\
(.003)\end{array}$ & $\cdots$ & $\begin{array}{l}.014 \\
(.005)\end{array}$ & $-\cdots$ & $\begin{array}{l}-.021 \\
(.001)\end{array}$ \\
\hline & .075 & .119 & .084 & .145 & .090 & .194 & 033 & .131 \\
\hline Sample Size & & 028 & & & & & & 891 \\
\hline
\end{tabular}

Notes: Standard errors are reported in parentheses. The regressions in columns (2) also include a variable indicating if the worker resides in a metropolitan area, as well as an interaction of that variable with immigration status. The regressions also interact the age, education, and metropolitan residence variables (where appropriate) with the period effects. The reported age and education coefficients are those obtained in the 1990 Census. 
TABLE A-2. REGRESSION USING POOLED 1970, 1980, AND 1990 CENSUSES FOR ETHNIC GROUPS INCLUDING AGE-AT-MIGRATION

(Dependent Variable $=$ Log Wage Rate, Using Age/Education Deflator)

Mexican

Variable

Intercept

Age

Age $^{2}$

$\mathrm{Age}^{3} \times 10^{-4}$

Immigrant $(=1)$

Years-Since-

Migration

(Years-Since-

Migration) ${ }^{2}$

(Years-Since-

Migration) ${ }^{3} \times 10^{-4}$

1980-1984 Arrivals

1975-1979 Arrivals

1970-1974 Arrivals

1965-1969 Arrivals

1960-1964 Arrivals

1950-1959 Arrivals

Pre-1950 Arrivals

1970 Period Effect

1980 Period Effect

Age-at-Migration

Years of Schooling

Education $x$

Immigrant

$\mathrm{R}^{2}$

Sample Size$$
\text { (1, }
$$

$-.231$

$(.0001)$

.029

(.011)

.031

(.010)

(.012)

.162

(.015)

(.019)

.251

304

.304

(.038)

$-.309$

$-.086$
Other Hispanic

(1) (2)

$\begin{array}{rr}.117 & -.847 \\ \text { (131) } & (.831)\end{array}$

(.131) (.131)

$.092 \quad .086$

$(.010) \quad(.010)$

$\begin{array}{ll}-.002 & -.002 \\ (.000) & (.000)\end{array}$

$\begin{array}{ll}.000) & (.000) \\ .117 & .097\end{array}$

$\begin{array}{ll}(.019) & (.018) \\ -.231 & .208\end{array}$

(.025) (.037)

$.010 \quad .010$

$(.002) \quad(.002)$

$\begin{array}{ll}-.0004 & -.0004\end{array}$

.033

(1)

$-.461$

(.159)

.121

(.012)

$-.003$

$(.000)$

.162

(.022)

$-.250$

(.032)

(2)

$-.897$

(.158)

.102

(.011)

$-.002$

$(.000)$

.126

(.021)

.065

(.051)

.014

$(.002)$

$-.0004$

.017

(.003)

-.0004
$(.0001)$

.035
$(.017)$

.035
$(.017)$

.041

(.017)

(.011)

.027

.034

(.012)

.007

(.014)

.057

.086

.122

(.014)

(.021)

(.015)

.190

(.018)

.096

.096
$(.029)$

$(.022)$

.160

.204

(.021)

(.028)

$(.021)$
347

.069

(.037)

.129

(.025)

(.046)

(.034)

.197
$(042)$

.317

(.032)

.071

(.059)

$.255 \quad .123$

(.059)

$-.272$

.360

.021

(.086)

$(.049)$
-.236

$-.133$

(.039)

(.057)

$-.229$

$-.105$

(.033)

$-.133$

(.023)

.006

$-.010$

$-.005$

(.001)

(.001)

.044
$(.002)$

.011

(.002)

$(.002)$

$.075 \quad .119$

96,028

.084 .144

63,816
Asian

White

$\begin{array}{cccc}(1) & (2) & (1) & (2) \\ -1.569 & -1.532 & -.819 & -1.393 \\ (.170) & (.177) & (.051) & (.049) \\ .192 & .151 & .132 & .109 \\ (.012) & (.012) & (.004) & (.004) \\ -.004 & -.003 & -.002 & -.002 \\ (.000) & (.000) & (.000) & (.000)\end{array}$

$\begin{array}{llll}.203 & .165 & .124 & .092\end{array}$

(.023)

$-.077$

(.022)

$-.258$

(.089)

.008

.009

$(.003)$

$-.001$

(.003)

$-.0004$

(.0001)

$.060 \quad .034$

(.016)

(.016)

.037

(.012)

(.013)

.141

(.016)

(.021)

.228

(.030)

(.023)

.324

(.030)

.271

(.039)

.375

.320

(.037) (.049)

.349

.324

(.046) (.061)

.275

(.067)

.389

(.088)

$-.194 \quad-.533$

(.060) (.085)

$\begin{array}{ll}-.047 & -.258\end{array}$

$(.027) \quad(.036)$

$-.009$

$(.001) \quad(.001)$

$(.007) \quad(.006)$

$\begin{array}{ll}.055 & .209\end{array}$

(.010) (.013)

$.011 \quad .015$

(.001) (.001)

$-.0003 \quad-.0004$

$(.0001) \quad(.0001)$

$.022 \quad .027$

(.005) (.005)

$\begin{array}{ll}-.002 \quad .007 \\ (.011) & (.011)\end{array}$

(.011) (.011)

$.036 \quad .003$
$01010)$

(.010) (.010)

$-.130 \quad-.034$

(.011) (.012)

$\begin{array}{ll}.086 & -.027\end{array}$

(.010) (.012)

$-.071 \quad-.041$

(.011) (.014)

$-.074 \quad-.066$

$(.011) \quad(.016)$

$-.043 \quad-.084$

(.012) (.021)

$.066 \quad .135$

$\begin{array}{ll}(.008) \quad(.012) & 0\end{array}$

$.082 \quad .025$

$\begin{array}{ll}(.007) \quad(.011) & 0\end{array}$

$\begin{array}{ll}-.002 & -.002\end{array}$

$(.000) \quad(.000)$

$\begin{array}{lllll}- & .037 & \ldots & .057\end{array}$

$$
(.005)
$$

.016

$\cdots \quad-.014$
.090
$(.005)$
$.033 \quad .131$

Notes: Standard errors are reported in parentheses. The regressions in column (2) also include a variable indicating if the worker resides in a metropolitan area, as well as an interaction of that variable with immigration status. The regressions also interact the age, education, and metropolitan residence variables (where appropriate) with the period effects. The reported age and education coefficients are those obtained in the 1990 Census. 